\title{
Value-added Trade, Exchange Rate Pass-Through and Trade Elasticity: Revisiting the Trade Competitiveness *
}

\author{
Syed Al-Helal Uddin ${ }^{\dagger}$ \\ Florida International University
}

October 1, 2016

\begin{abstract}
How is exchange rate pass-through (ERPT) measure affected by increasing participation in global value chains? This paper measures ERPT for value-added trade, where production of exportable intermediate inputs requires sharing among countries in a back-and-forth manner for producing a single final product. Estimation of pass-through was done using World Input-Output Database (WIOD), World Economic Outlook (WEO), and OECD statistics. Empirically estimated findings suggest that ignoring the value-added trade will cause a systematic upward bias in the estimation of ERPT. From empirical investigation, it is also evident that there exists substantial heterogeneity in pass-through rates across sectors: sectors with high-integration into global market functions with a lower rate of exchange in comparison to sectors with less integration.
\end{abstract}

JEL Code: F14, F23, F41, L16

Key Words: Value-added trade, Pass-Through, Trade Competitiveness, Intermediate inputs, Production Sharing

*I would like to thanks Hakan Yilmazkuday and Zaki Eusufzai for their valuable comments. I would also like to thanks participants in the 91st WEAI and 85th SEA conference attendee, and graduate seminar attendee at the Economics department in FIU.

$\dagger$ Ph.D. Candidate, Department of Economics, suddi002@fiu.edu 


\section{Introduction}

In international economics, prices and exchange rates lie at the heart of classic academic and policy analysis. The exchange rate affects domestic price-level directly through imported final goods and indirectly through imported inputs used in domestic goods production. ${ }^{1}$ Conventional trade theory predicts that exchange rate increases (in other words devaluation) will increase exports. On the other hand, imports become more expensive. When the exports of a country are produced using imported intermediary inputs, then the effectiveness of exchange rate policy becomes complex. Empirical studies have paid little attention toward this indirect channel, may be due to required data limitation. Under the liberalized trade era with freer the factor (capital and labor) movements, technological improvements, lower transaction and communication costs, and information availability expediated cross-boarder production sharing. The recent availability of input-output tables across countries and over time revealed the supply side information about the production stages of a single product compared to the traditional demand side information. ${ }^{2}$ This supply side information raised some question regarding the effectiveness of exchange rates as an automatic stabilizer in open economy macroeconomics. Therefore, the central question in international finance remains whether exchange rates pass-through is complete or incomplete, and is it heterogeneous across sectors or not?

This paper consider a back-and-forth ${ }^{3}$ trade structure as follows: assume

\footnotetext{
${ }^{1}$ Literature explains the relationship between prices and exchange rates using the relative purchasing power parity (PPP) which states that changes in price of a product should be same across markets after converting it into a common currency (Burstein and Gopinath, 2014). Cassel (1921) developed the notion of relative PPP from the idea of Law of One Prices (LOP), which states that without arbitrage condition, identical goods sold in different markets must have same price. PPP is the aggregated version of LOP, where instead of a single product a set of product is used to construct an Index: Consumer Price Index (CPI).

${ }^{2}$ Using input-output information across countries, Johnson (2014) found that the valueadded exports share is lower than the gross exports share in total trade.

${ }^{3}$ In this paper back-and-forth trade considers the case when exported products are produced with imported raw materials and imported products are produced with the exported items. See Chungy (2012); Timmer et al. (2014b); and Hummels et al. (2001) for more on global value chain or production fragmentation, which is the basic idea of back-and-forth trade structure.
} 
there are four countries in the world; namely Bangladesh (B), India (I), China $(C)$, and the USA $(U)$, engaged in a global value chain of trade. In this hypothetical trade structure, countries are producing apparel and textile products. Figure 1 presents the illustrated view of the proposed production structure. In stage one, country $C$ and $I$ produce raw materials (cottons) for the production of textiles. In stage two, countries $C$ and $I$ ship it (cotton) to country $B$, and they refine it and make threads. In stage three, country $B$ uses part of the thread to produce fabrics in their own country and part of that is exporting to country $C$ for making different quality fabrics. In stage four, country $C$ is exporting their fabrics to country $B$ for cutting, stitching and finalizing the product for retailers. In stage five, the final product is exported to country $U$, whereas $U$ had sent the design in the very first place. It may appear from the label of the product that it is made in country $B$, though, country $B$ has a small fraction as value-added share in the total production process.

Traditional trade theory predicts that a depreciation of country $B^{\prime}$ s currency makes their goods cheaper to foreigners, which implies that their export increases to country $U$. On the other hand, exports from country $C$ or country $I$ decrease to country $U$. The global value chain shows that demand for raw materials from country $C$ and country $I$ increases due to the higher demand for country $B^{\prime}$ s exportables. Empirical studies in international finance overlooks this secondary channel. This paper examines how does exchange rate change pass-through to relative prices of exports and imports with increasing participation in back-and-forth trade? Does this pass-through change the conventional notion of the relationship between exchange rates and trade?

There have been several studies on different branches of production fragmentation, global value chain trade and their welfare effects: both in theoretical and empirical settings. However, there have been limited number of studies, compared to other subbranches, on exchange rate pass-through un- 
Figure 1: Back-and-forth trade structure for apparel and textile products

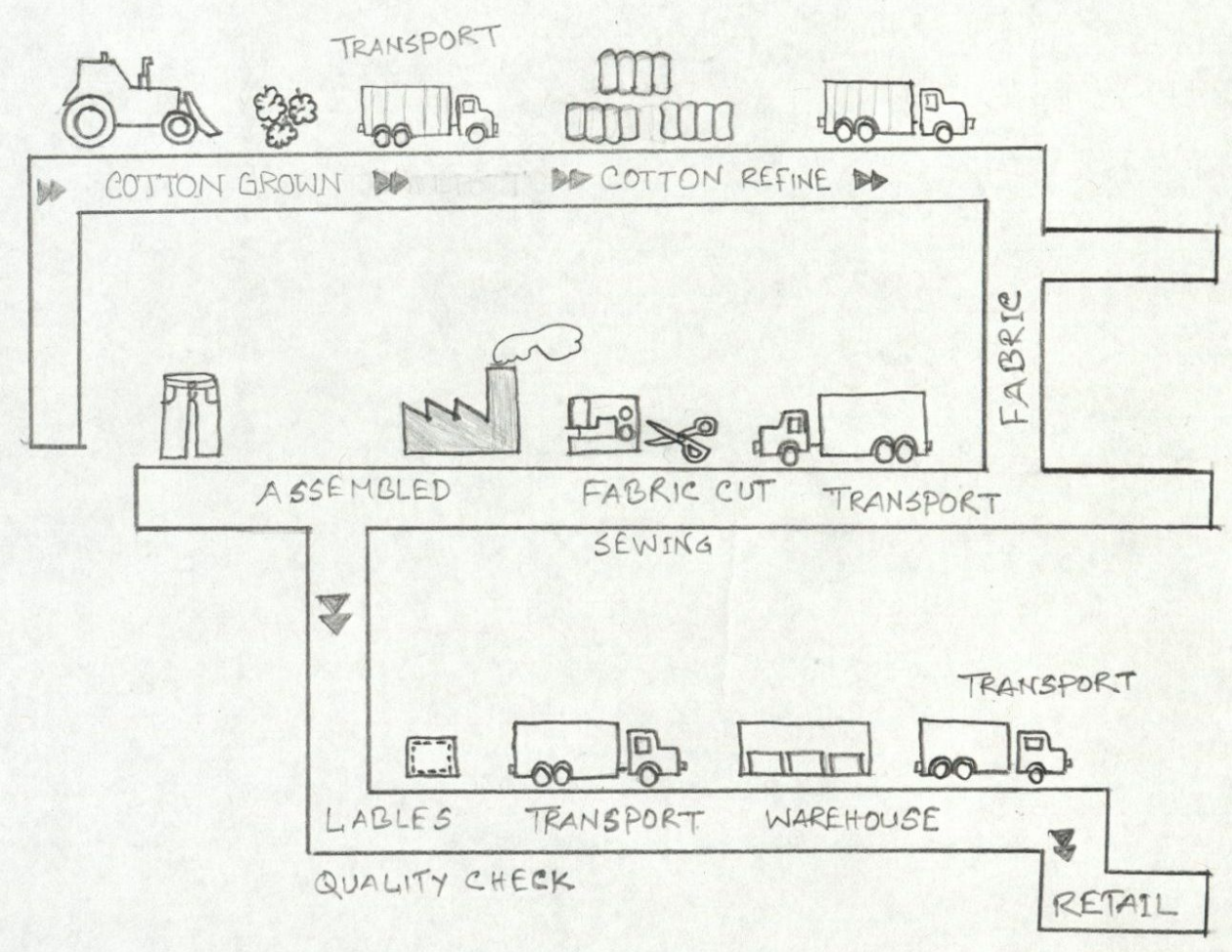

der production sharing or global value chain trade. We found three studies which examined the relationship between production sharing and exchange rate pass-through. Ghosh (2009) theoretically studied the impact of exchange rate movement on cross-boarder production, while Ghosh (2013) empirically tested the responsiveness of trade between Mexico and the USA focusing on production sharing exports. Powers and Riker (2013) studied exchange rate pass-through behavior under value added trade. However, none has studied the back-and-forth nature of production and the value added export to analyze the effectiveness of exchange rate pass-through.

Johnson (2014) found that the ratio of world value-added to gross export (VAX) is about 70-75 percent of total trade, and has decreased over time by roughly ten percentage points. They also summarized that the VAX ratio is relatively smaller for manufacturing, and larger for outside of manufacturing, specially in service sector, VAX ratio changes are heterogeneous across coun- 
tries, fast growing countries facing the larger declines, the gap between bilateral value-added and gross exports are large and heterogeneous across trade partners.

Figure 8 - 13 presents bilateral exports, imports and exchange rate growth during 1995-2001. Here, positive growth of exchange rate implies exchange rate depreciation and negative growth rate implies appreciation relative to foreign currency. For example, figure (8) shows that export, import and exchange rate change during 1995-2011 between USA and Germany. From the figure it is also evident that during 1995-2000, the United States dollar appreciate against the Deutsche Mark, the USA import increases from Germany, and interestingly the United States exports increases to Germany. Figures $8-13$ shows some contradicts with traditional theoretical prediction that when exchange rate appreciate, export falls; on the other hand, import rises.

This paper contributes to the literature of international trade and finance by examining a new production structure, where inputs are sharing among countries in several stages. The empirical estimation for bilateral trade by sectors uses data from the World Input Output Database (WIOD). The database contains time series data on the international sourcing of intermediate inputs and final goods in 35 sectors among 40 countries (27 EU and 13 other major countries) for 1995-2011. The WIOD database contains data on sectoral trade, domestic expenditure, and final expenditure and sectoral value added (labor and capital) in production. From the input-output table, we estimate the sources of value added in final goods traded and consumed in the world.

This paper has similarity with Powers and Riker (2013) in terms of the empirical estimation technique. In contrast to value-added trade as used by Powers and Riker (2013), we used a back-and-forth production structure to determine the value-added trade that crossed border multiple times for the production of a single product. To construct the variable of interest (i.e., back-and- 
forth export), this paper uses Wang et al. (2013)'s technique to separate domestic value-added that absorbed abroad and returned in home after some value addition. This paper also has some similarity with Gaulier et al. (2008) and Campa and Mínguez (2006) in terms of the empirical estimation procedure. Gaulier et al. (2008) studied exchange rate pass-through (ERPT) at the product level for Canadian goods exported to the united states, while Campa and Mínguez (2006) studied ERPT for EURO countries. This paper combines both sectors and countries over time. We did our estimation by sectors and also by countries.

From the empirical estimation, we found that the median pass-through rate is 0.119 , while the pass-through rate for the manufacturing sector is 0.112 and the pass-through rate for the service sector is -0.01 . Our estimated pass-through is higher than Powers and Riker (2013), ${ }^{4}$ but similar to the value of Campa and Mínguez (2006) and Marazzi et al. (2005).

A significant amount of literature has studied the macroeconomic implications of invoicing currency choice and associated trade effects. The real effective exchange rate (REER) is one of the most important indices to policy makers and academia for welfare analysis, as well as to understand exports competitiveness. ${ }^{5}$ The REER also measures change in competitiveness due to the change in the demand for goods produced by a country as a function of changes in relative price (Patel et al. (2014), Saito et al. (2013), Powers and Riker (2013)). Competitiveness arises as changes (fall) in the cost structure of a producer make their product more competitive by enabling it to capture demand from other producers (Patel et al., 2014), therefore it is important to decompose the role of

\footnotetext{
${ }^{4}$ Using the WIOD databese, and excluding 12 smaller countries and service sectors from their empirical estimation, Powers and Riker (2013) found the median pass-through rate for manufacturing sector is 0.44 . They also restricted their analysis only for the period of 20002009.

${ }^{5}$ The standard REER indices measured by BIS and IMF used in their surveillance are based on gross trade rather than trade in intermediate goods. The most widely-used indicies published by the IMF and the Bank of England uses bilateral export shares or import shares or trade (exports plus imports) shares as their weights (Bayoumi et al., 2006).
} 
competitiveness, which arises from change in REER. Global value chain trade provides new weights that depend on both the global input-output structure and relative elasticities in production versus demand (Bems and Johnson, 2015).

According to the above described trade structure, an increase in prices for textile raw materials in country $C$ or country $I$ could very well lead to a decline in demand for country $B^{\prime}$ s products, even though in country $B$ everything remains the same and hence there is a decline in competitiveness. This paper decomposes trade elasticity into two parts: own price and price index effect. Own price effects capture the cost increase due to increase in raw materials price from an exchange rate shock. We found that there is a substantial heterogeneity both in own price and cross-price elasticities across sectors and across countries. For example, we find that for a 10\% increase in the nominal exchange rate of Renminbi to USD (10\% depreciation of Renminbi relative to USD) will increase China's export of agricultural, forestry and fisheries by $2.3 \%$. Further, we found that due to negative effect of own price effect, export decreased by $0.19 \%$, while positive price effect export increases by $2.5 \%$.

This paper is organized as follows: section 2 describes some recent literature on global value chain trade, real exchange rate measurement, and competitiveness issues. Section 3 describes the methodology and data for examining the difference between other approach and this approach. Section 4 discusses the empirical findings from the data. Finally, section 5 concludes.

\section{Literature Review}

Since the early 1980s, there has been considerable amount of literature on exchange rate pass-through (ERPT) mainly in advanced countries. The new open economy macroeconomics gives some theoretical guidelines for empirical estimation of ERPT. Although previous research explained the ERPT as the changes of consumer prices due to change in exchange rate, recent studies exchange 
rate pass-through as the change of producer prices or consumer prices due to a change in import prices. The effect of exchange rate pass-through depends on both time dimension and pricing strategy. Under the producer currency pricing (PCP), prices are determined in exporters' currency, then import price passes completely. On the other hand, local currency pricing (LCP) exporters' prices varies with the exchange rate changes but the destination (importer) prices are stable. However, complete pass may occur if production process is happening under perfect competition and incomplete pass-through in imperfect competitive environment.

Now-a-days, production processe becomes more complicated with several stages of imported intermediate inputs. The measure of real effective exchange rate also becomes more complicated than before. In consequence to the multistage production process, traditional trade statistics become increasingly less reliable for defining the margin of contribution made by each single country. Hummels et al. (2001), in their seminal paper, came up with the idea of vertical specialization (VS) in production processes. They focused on the multipleborder-crossing and back-and-forth aspect of trade. As per their assumption under vertical specialization, a good is produced in at least two sequential stages, at least two countries provided value-added during the production of the good, at least one country must use imported inputs in the production process, and part of the output must be exported. Using input-output table information from 14 countries (10 OECD and 4 emerging economies) for the period of 1960-1990, they found that the VS share of merchandise exports for the 10 OECD countries was 0.20 and smaller countries have VS shares as high as 0.4, on average. Moreover, for the entire sample they found the VS share grew by about $30 \%$ during the time period, and growth in VS exports accounted for $30 \%$ of the growth in the overall export/GDP ratio.

However, when a country exports processing goods, then vertical special- 
ization with multi-stage processes will give a biased result. Koopman et al. (2012) also mentioned that when more than one country is exporting intermediate goods, then the VS trade, like Hummels et al. (2001) mentioned, will not hold. Recent literature on REER using global input output structure uses the Global Trade Analysis Project (GTAP) database (Johnson and Noguera (2012), Koopman et al. (2014), Daudin et al. (2011)), the World Input-Output database (WIOD) (Koopman et al. (2012, 2014); Wang et al. (2013)), the OECD-WTO TiVA Database to explore this issue.

As the production process became more fragmented, standard official gross trade statistics account the total value of goods at each border crossing, rather than the net value added at each crossing point. Johnson and Noguera (2012) computed the value-added content of trade combining global input-output tables with bilateral trade data for several countries. They separated gross output of a country by destination where it is absorbed in their final demand then they used value added to output ratios for the country of origin to compute the value added output transfer to each destination. They mapped where the value added were produced and where it was absorbed. For the empirical estimation, they used the GTAP database 7.1, which includes bilateral trade statistics and input-output tables for 94 countries, plus 19 composite regions covering 57 sectors in 2004. From their empirical estimation, they concluded that value added to gross export (VAX) ratio varies extensively across sectors and countries. Moving from aggregate to bilateral data, they found the VAX ratio also varies substantially across partners for individual countries. They claimed this difference is mainly due to their decomposition methodology.

Augmenting the Armington (1969) framework, with cross-border input linkages, which consists of global bilateral input-output accounting framework, Bems and Johnson (2012) re-defined the formula for measuring real effective exchange rate for trade in value-added. For their formulation, they assumed that 
gross output in an economy is produced aggregating domestic value-added with domestic and imported intermediaries. They used trade measured in value-added terms to create bilateral weights, which differs from standard calculation as used in gross trade flows. They used global input-output tables from the GTAP database to create the weight matrix, and as a measure of prices of real value added as a GDP deflator for 42 countries from 1970 to 2009. They asserted that their value-added REER differs from the standard REER in both data sources to construct the weight matrix to aggregate bilateral price changes and measure of the price changes itself. They concluded that their estimated value-added REER differs significantly from the standard REER.

Measuring competitiveness when trade is happening in a back-and-forth setting can be defined from REER. Intermediate inputs sharing in production process change the relative price of goods, but are less sensitive to the domestic factor price movement. Bayoumi et al. (2013) formulated a new index of REER and named it REER-goods, where goods are produced using both domestic production inputs and foreign production inputs. They incorporated price of goods as a function of price of production factors, which was also embedded in goods. They concluded that their result capture a depletion in competitiveness due to a rise in relative factor costs or an appreciation of nominal exchange rate. In determining the price index, they used two-level constant elasticity of substitution (CES) functional form as the production technology, which separated domestic value-added and foreign value-added used in the domestic production instead of using one CES price aggregator, like Armington (1969). For empirical estimation of their model, they used both the OECD bilateral trade database and the Input-Output database, with the UN-Comtrade database to define intermediate inputs sharing among countries, and for price measure they used GDP deflator from the World Economic Outlook (WEO) from the International Monetary Fund (IMF). 
For a tractable and empirically replicable formulation, Koopman et al. (2014) provided a unified accounting framework, which can fully account for a country's gross exports by its various value-added (domestic value-added that return home and foreign value-added) and double counting components. Their framework considered measure of vertical specialization and value-added trade, which solved the problem of back-and-forth trade of intermediates cross border multiple times. They proposed an accounting framework for avoiding the double counted problem in the existing official trade statistics. For the empirical estimation for their theoretical framework, they used the GTAP database 7 along with the UN-COMTRADE database and quadratic mathematical programming model to construct a unique data-set. The new database covers 26 countries and 41 sectors.

However, with the availability of a more structured database, it was found that the value-added export (VAX) ratio has two limitations. Wang et al. (2013) identified that VAX ratio can not consistently explain sectoral, bilateral or bilateralsectoral level fluctuations consistently. They also pointedout that even after reformulation, some of the important features like the back-and-forth nature of value addition by sectors cannot be explained by the value added export ratio as proposed by Johnson and Noguera (2012). From Koopman et al. (2014), it was exposed that total gross exports of a country can be decomposed into domestic value addition, foreign value addition and also detect the double counted value added portion for the countries. However, this method cannot differentiate sectoral, bilateral or bilateral-sector level value addition. Exports in a given sector from a country use value added from other sectors in the same country, value added from both the same sectors and other sectors in other countries (Wang et al., 2013). Augmenting Koopman et al. (2014)'s framework and incorporating the above limitations, Wang et al. (2013) applied the gross exports decomposition formula to bilateral-sector level data. Their decomposi- 
tion framework can explain any level of disaggregation from gross trade flows into domestic value-added engrossed in abroad; domestic value added that is initially exported but eventually returned home; only foreign value-added; and pure double counting terms.

Patel et al. (2014) offered a theoretical framework to compute REER focusing on competitiveness using four features that have been missed and caused a biased or mis-measured estimate of competitiveness. They classified the category of trade between intermediate and final based on the end user category. After separating trade in intermediate inputs, value added output and gross output, they defined and computed REER indices to quantify competitiveness both in terms of gross output (Q-REER) and value added (GVC-REER). By using their multi-sector, multi-country theoretical model, and exploiting detailed sector level trade flows data, they have computed those sectoral REER indicies within countries. They explicitly estimated and incorporate different elasticities of substitution in production functions and final demand aggregators in their REER indices, instead of assuming all elasticities to be unity as is commonly done in the literature.

The advancement of global supply chains and intermediate inputs sharing present a ultimatum for the traditional multi-sector macro models. Recent literature documented the importance of re-defining the measurement of exchange rate fluctuation, as well as the effectiveness (Thorbecke and Smith (2010); Purfield and Rosenberg (2010); Cheung et al. (2012)). In a multi-country, multisector production, both foreign and domestic inputs play an important role in external sector adjustment. Mismeasured preference weights and price elasticity parameters from traditional value added model give a biased result in relative price response. Bems (2014) decomposed the deviation due to price fluctuation into "imported input" and "domestic input" category based on preference weights. Imported input lowers barriers to economic openness, and thereby 
increases responsiveness of relative price to a given external adjustment, i.e., traditional value added model understate price adjustment. Domestic input increases service embedded manufacturing trade or lowers net manufacturing trade, therefore, traditional value added model overstates the price adjustment. He also showed that those mis-measurement overstates CES price elasticity and interaction of both preference and weight effects and price elasticity understates the price response effects.

Though majority of the literature shows that exchange rate pass-through is both linear and symmetric, Bussiere (2013), investigated the assumptions of linear-nonlinear issues for export and import prices in the G7 economies and asserted that non-linearities in the reaction of profit margins to exchange rate movements, which may appear for the price rigidities and switching costs. He defined non-linearities by augmenting a standard linear model with polynomial functions of the exchange rate and with interactive dummy variables. $\mathrm{He}$ concluded that neither non-linearities nor asymmetries can be avoided, and their magnitude varies noticeably across countries .

Recent research also showed that exchange rate has a lot of variation over last decades, whereas in comparison to that price has changed a little in comparison. Amiti et al. (2014) found that larger exporters were the larger importers as well. They showed that the value of a country's currency is associated with its trade partners through the imports of intermediate inputs, which reduces the need for exporters to adjust their export market prices. To check their theoretical framework, they used firm-level data for Belgium and found that exporters' with larger imported input share passes lower exchange rate variation into export prices. They digged their results a bit more and decomposed it into several channels and found that higher import-intensive firms have the higher export market shares. They concluded that small exporter with no imported inputs have a nearly complete pass-through, while a large import-intensive exporter 
has a pass-through just above $50 \%$, at an annual horizon.

Economic models for accounting exchange rate pass-through relie on the assumption that exporters are denominated into exporters' currency fully and the exports items are fully produced with exporters' own value addition Powers and Riker $(2013,2015)$. However, as global value chain estimation become forthright, calculating the share of costs structure for exports become easier. Using the input-output tables, Powers and Riker (2013) calculated the exchange rate pass through coefficient for 28 countries for 13 manufacturing sectors. They found that exchange rate pass-through denominated in the costs of exporters' currency are inclined to understate the pass-through rates and to overstate the adjustment of the exporters mark-ups to movements in exchange rates. They also find that without incorporating value-added trade, trade elasticity estimates are systematically overstated.

\section{Methodology and Data}

\subsection{Model}

This structural model is derived form (Bems and Johnson, 2015) and (Powers and Riker, 2013) to estimate exchange rate pass-through which accommodate value-added trade into there. This section is divided into two parts. In the first part, we derived the estimable equation of exchange rate pass-through using value added trade, prices, exchange rates. In the second part, we derived the trade elasticity based on the parameters driven in part one and value added trade information.

\subsubsection{Exchange Rate Pass-Through}

Let's assume that the world economy consists with many countries $(i, j$, and $k \in\{1,2, \ldots, N\})$. Each country follows Armington type production function to 
produce a tradable goods in sector $s$ using both intermediate and final goods. Country $i$ 's total output, $Q_{i}$, is produced combining both domestic value-added, $X_{i}$, and the composite intermediate inputs, $V_{i}$. The composite intermediate inputs are the aggregate of domestic and foreign imported inputs, where inputs are imported from country $j$ to country $i$. The production process follow nested constant elasticity of substitution (CES) form:

$$
Q_{i, t}=\left(\left(\alpha_{i}^{\chi}\right)^{1 / \gamma} X_{i, t}^{(\gamma-1) / \gamma}\right)^{\gamma /(\gamma-1)}+\left(\left(\alpha_{i}^{\nu}\right)^{1 / \gamma} V_{i, t}^{(\gamma-1) / \gamma}\right)^{\gamma /(\gamma-1)}
$$

and

$$
V_{i, t}=\left(\sum_{j}\left(\frac{\alpha_{i j}^{\nu}}{\alpha_{i}^{v}}\right)^{1 / \sigma} V_{i j, t}^{(\sigma-1) / \sigma}\right)^{\sigma /(\sigma-1)}
$$

St.

$$
\sum_{j} P_{i j, t} V_{i j, t}=Y_{j}
$$

where the $\alpha^{\prime}$ s are aggregation weights, $\gamma$ is the elasticity of substitution between domestic value added and the composite intermediate input, and $\sigma$ is the elasticity of substitution among composite inputs.

Solving the maximization problem in (3.2), first order condition yields as follows:

$$
P_{i j, t} V_{i j, t}=\left(\frac{\alpha_{i j}^{v}}{\alpha_{i}^{v}}\right) P_{i, t}^{\sigma}\left(P_{i j, t}\right)^{1-\sigma} V_{i, t}
$$

With CES demand preferences for a product in sector $s$, intermediate inputs from distinct countries are imperfect substitutes to each other with a elasticity of substitution of $\sigma$. Relative expenditures on different products is a constant elasticity of the relative prices in the consumers currency.

$$
\frac{V_{i j, t}}{V_{j j, t}}=\left(\frac{\alpha_{i j}^{\nu}}{\alpha_{j j}^{v}}\right)\left(\frac{P_{i j, t}}{P_{j j, t}}\right)^{1-\sigma}
$$

Here $V_{i j, t}$ value of exports from country $i$ to country $j$ in the currency of $j$; $V_{j j, t}$ value of export in the destination country $j$ in the currency of $j ; P_{i j, t}$ price of 
exports from country $i$ in the currency of country $j ; P_{j j, t}$ price of domestic export in currency $j$. As this equation is sector specific, therefore, any subscription for sector is avoided.

Taking total differentiating and using "hat" algebra, we can write (3.4) as follows:

$$
\hat{v}_{i j, t}-\hat{v}_{j j, t}=(1-\sigma)\left(\hat{p}_{i j, t}-\hat{p}_{j j, t}\right)
$$

$\hat{P}_{i j, t}$ is the weighted average of the imported inputs prices for the exports at source country currency, $p_{k k, t}$ divided by the exchange rate of source country to country $j, E_{k j, t}$ with an additional mark-up $\lambda$. This $\lambda$ captures the exchange rate pass-through coefficient.

$$
\hat{p}_{i j, t}=\lambda \Sigma_{k} \theta_{k i, t}\left(\hat{p}_{k k, t}-\hat{E}_{k j, t}\right)
$$

$\theta_{k i, t}$ captures the cost share of country $k^{\prime}$ s exports in the sector $s$ in country $i$ at year $t$. Using equation (3.5) and (3.6)

$$
\hat{v}_{i j, t}-\hat{v}_{j j, t}=-(1-\sigma) \hat{p}_{j j, t}-\lambda(1-\sigma) \Sigma_{k} \theta_{k i, t}\left(\hat{p}_{k k, t}-\hat{E}_{k j, t}\right)
$$

For the empirical econometric estimation, I used equation (3.6) in the following fashion:

$$
\hat{v}_{i j, t}-\hat{v}_{j j, t}=\beta_{0}+\beta_{1} \hat{p}_{j j, t}+\beta_{2} \Sigma_{k} \theta_{k i, t}\left(\hat{p}_{k k, t}-\hat{E}_{k j, t}\right)+\eta_{i j, t}
$$

Here, the error term $\left(\eta_{i j, t}\right)$ follows conventional distribution. From the econometric regression, we can retrieve the exchange rate pass-through, $\lambda$, as $\left(-\beta_{2} / \beta_{1}\right)$ and the elasticity of substitution as $\sigma$ can be retrieved as $1+\beta_{1}$. 


\subsubsection{Trade Elasticity}

In order to calculate the trade elasticity, we used the same CES preferences structure, however, instead of relative demand, we used relative expenditures on exports from country $i$ to country $j$ as follows:

$$
V_{i j, t}=Y_{j, t}\left(P_{j, t}\right)^{\sigma}\left(P_{i j, t}\right)^{-\sigma}
$$

$Y_{j t}$ total consumer expenditure in a sector in the country $j ; P_{j t}$ is the CES price index in country $j$ for a sector $s$.

Taking total differentiating and using hat algebra,

$$
\hat{v}_{i j, t}=\hat{y}_{j, t}+\sigma\left(\hat{p}_{j, t}-\hat{p}_{i j, t}\right)
$$

where, $\hat{p}_{j, t}$ is the expenditure weighted average of percentage changes in the prices of imports from all source countries.

$$
\hat{p}_{j t}=\Sigma_{k} \gamma_{k j, t} \hat{p}_{k j, t}
$$

where, $\gamma_{k j, t}$ is the share of exports from country $k$ to country $j$ in the total expenditures of the country $\mathrm{k}$ in year $t$. Substituting equation (3.5), (3.10) into (3.9) and setting $\hat{y}_{j, t}=0$, yields as follows:

$$
\begin{gathered}
\hat{v}_{i j, t}=\sigma\left(\Sigma_{k} \gamma_{k j, t} \hat{p}_{k j, t}-\lambda \Sigma_{k} \theta_{k i, t}\left(\hat{p}_{k k, t}-\hat{E}_{k j, t}\right)\right) \\
\hat{v}_{i j, t}=\sigma \lambda \Sigma_{k} \theta_{k i, t} \hat{E}_{k j, t}+\sigma\left(\Sigma_{k} \gamma_{k j, t} \hat{p}_{k j, t}-\lambda \Sigma_{k} \theta_{k i, t} \hat{p}_{k k, t}\right)
\end{gathered}
$$

Now setting $\hat{P_{i j, t}}=0$ for all $i$ and $j$, and using exchange rate as the relative currency prices between country $i$ and country $j$, we can write (3.11) as follows:

$$
\hat{v}_{i j, t}=-\sigma\left(-\lambda \theta_{i i t} \hat{E}_{i j t}+\lambda \Sigma_{k} \theta_{i k t} \gamma_{k j t} \hat{E}_{i j t}\right)
$$


From equation (3.13), we derived trade elasticity as the percentage change in the value of exports from country $i$ to country $j$ in response to a one percent increase in $E_{i j t}\left(\right.$ i.e., $\left.\frac{d \hat{v}_{i j, t}}{d \hat{E}_{i j t}}\right)$. Then we decomposed the trade elasticity into two parts: own price effect and price index effect.

$$
T E_{i j, t}=\underbrace{-\sigma \lambda\left(-\theta_{i i, t}\right)}_{\text {own price effect }}+\underbrace{(-\sigma \lambda) \Sigma_{k} \theta_{i k, t} \gamma_{k j, t}}_{\text {prices index effect }}
$$

From equation (3.14), we expect that the trade elasticity is positive. The own price effect is always positive, and it is increasing in country $i^{\prime} s$ share of the value added in its own production in the sector. The price index effect is always negative, and it is declining in the country $j$ expenditure-weighted average of country $i^{\prime} s$ share of the value added in the production of each country that exports to country $j$ (Powers and Riker, 2013).

\subsection{Data}

The world's export-to-output ratio grew from 20 to 25 percent during 19952009 , this change is even more for south-east asian countries (specially in China from 23 to 39 percent) and northern Euro areas (Saito et al., 2013). This variation in output and gross exports might be, due to the production of same amount of output using more imported intermediate inputs, which cross boarders multiple times. In this section, we describe the available data sources, their advantages and disadvantages.

Figure $2{ }^{6}$ shows the bilateral trade between countries with top two exporting partners. Each country is represented by the nodes in the network and labeled by the three digit country code. Each color represents a geographical region where countries are situated. The circle size represents the degree of openness in global production, i.e., the larger the circle size, the higher the con-

\footnotetext{
${ }^{6}$ This figure is reproduced following CEPII network trade visualization methods. For details on Pajak and Stata module see CEPII
} 
Figure 2: Bilateral trade among countries with top importing and exporting pairs'

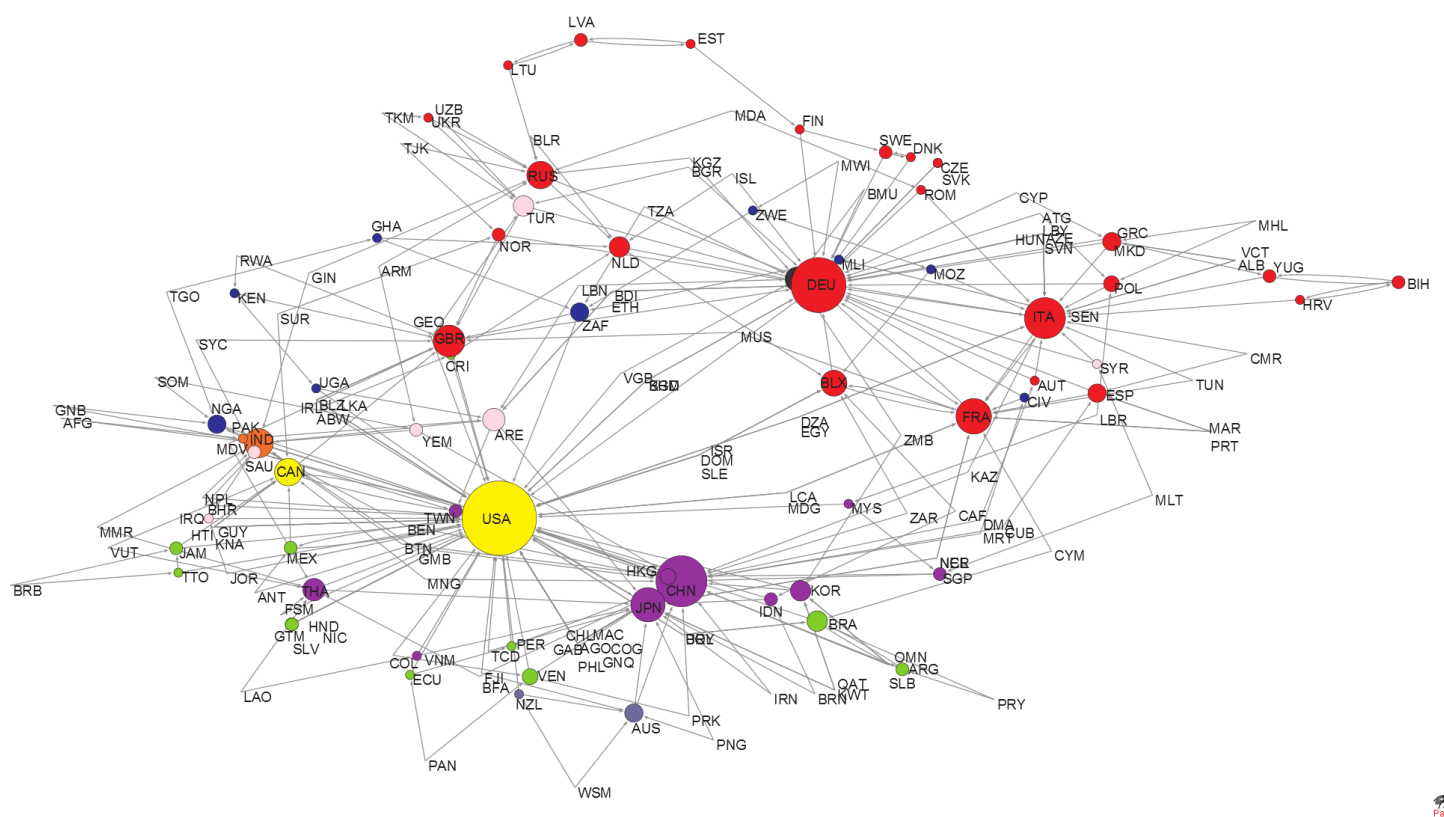

nection in global production system. This figure also depicts that when countries are trading more between them, they stayed closer (not in geographical position, but in the figure). For example, European countries have a higher trade among themselves, so they are placed in closer distance, while the United States, Japan and China are placed closer as they are more in recent time. From this figure it is evident that for analyzing cross-country production sharing by sectors, we need international input-output table (IIOT) data. The following section shades more light on IIOT database.

Figure 3 summarizes the available global input-output database. The WIOD database is developed and managed by European Commission. The WIOD covers 40 countries and 35 sectors during 1995-2011. The OECD and the WTO mutually developed an International Input-Output database to understand international trade. Although the OECD-WTO database have information on trade in value-added measure (TiVA), but the database is not continuous in terms of time dimension. The initial version of the OECD-WTO TiVA database had 58 economies and 37 sectors for the years 1995, 2000, 2005, 2008 and 2009, 
while the recent release have 61 economies with two more years, and 34 sectors instead of 37 sectors. The global trade analysis project (GTAP) has the most extensive and routinely updated database for this type of trade analysis. The current version of the GTAP database has 140 countries and 57 commodities. However, the information for this database is coming from unofficial sources, mostly submitted by the GTAP members. The Eora multi-region IO database provides a time series of high resolution input-output (IO) tables with matching environmental and social satellite accounts for 187 countries.

In this paper, we use the WIOD database over other global input output tables. This database has few advantages compared to others. Firstly, WIOD is constructed from world input-output tables (WIOT), which (WIOT) is designed to capture value added trade and consumption overtime using national account statistics from respective countries. Secondly, the WIOTs is constructed from national supply and use tables (SUTs), which are constructed from official statistical sources. ${ }^{7}$ Thirdly, apart from WIOTs, WIOD also provides socio-economic accounts (SEA) data on quantity and prices of input factors, workers and wages by level of educational attainment and capital inputs. Finally, WIOD is completely free, whereas the OECD-WTO has limited access, the GTAP database needs purchasing, and the IDE-JETRO has only one regional perspective rather the world as a whole.

Figure 4 shows a single country input-output table, where rows indicate supply of and columns indicate demand for an input. Industry by industry matrix represents the demand for and supply of intermediate across industries for a country. The domestic final use section shows how much of the intermediate inputs they are using domestically and how much they are exporting with a check sum of total use. The last section of table 4 shows the input linkages for the production process. However, this import does not have any information

\footnotetext{
${ }^{7}$ In contrast to WIOD, IDE-JETRO and GTAP has different benchmark year for different version of their dataset. The IDE-JETRO has limited number of countries only for Asian countries, while the EORA dataset has almost all the countries in the world.
} 
Figure 3: Sources of International Input-Output Tables (IIOTs)

\begin{tabular}{|c|c|c|c|c|}
\hline \multirow{2}{*}{ Database } & Data Source & \multicolumn{3}{|c|}{ Data Coverage } \\
\cline { 3 - 5 } & & Countries & Sectors & Years \\
\hline $\begin{array}{c}\text { World Input-Output } \\
\text { tables }\end{array}$ & $\begin{array}{c}\text { National supply-use } \\
\text { tables }\end{array}$ & 40 & 35 & $1995-2011$ \\
\hline $\begin{array}{c}\text { OECD-WTO TiVA } \\
\text { database }\end{array}$ & $\begin{array}{c}\text { National Input-output } \\
\text { tables }\end{array}$ & 61 & 34 & $\begin{array}{c}1995,2000, \\
2005,2008- \\
2011\end{array}$ \\
\hline $\begin{array}{c}\text { UNCTAD-EORA GVC } \\
\text { database }\end{array}$ & $\begin{array}{c}\text { National and regional } \\
\text { supply-use and I-O } \\
\text { tables }\end{array}$ & 187 & 25 & $1990-2010$ \\
\hline $\begin{array}{c}\text { Global Trade Analysis } \\
\text { Project (GTAP) }\end{array}$ & $\begin{array}{c}\text { I-O tables submitted } \\
\text { by GTAP members }\end{array}$ & 140 & 57 & 1997,2001, \\
& & & & 2004,2007, \\
& & & & 2011 \\
\hline
\end{tabular}

Figure 4: Single country input-output table structure

\begin{tabular}{|c|c|c|c|c|c|c|}
\hline \multirow[b]{2}{*}{ 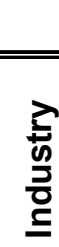 } & Industry & \multicolumn{2}{|c|}{ Final use } & Use & \multicolumn{2}{|c|}{ Supply } \\
\hline & Intermediate use & $\begin{array}{l}\text { Domestic } \\
\text { final use }\end{array}$ & Exports & $\begin{array}{c}\text { Total } \\
\text { use }\end{array}$ & \begin{tabular}{|c} 
Domestic \\
supply
\end{tabular} & Imports \\
\hline & $\begin{array}{l}\text { Value added by } \\
\text { labour and capital }\end{array}$ & & & & & \\
\hline & Gross output & & & & & \\
\hline
\end{tabular}

source: Timmer et al. (2014a) 
from where it is coming. For the construction of WIOTs, it is required crosscountry detailed import and export information.

Figure 7 shows the structure of the WIOD with only three countries setting, while in the WIOD database there are 40 countries plus rest of world by 35 sectors during 1995-2011. Figure 7 decomposes the imports from the source country by HS 6 digit level, then aggregating in 2 digit industries level. Intermediate use block shows the input requirements for the output production. It is possible to look for sectors in here and thereby dig more of the interested sector for a specific country. For example, to trace down the source of an intermediate input used in the production by industry 1 in country A, by looking at the associated column for country A. Final use columns are divided into several parts each country, such as, final consumption expenditure by household, final consumption expenditure by NGOs to household and government, gross-capital formation, change in inventory and total output. WIOTs also have some additional rows, as follows: total intermediate consumption, taxes less subsidies on products, cif/fob adjustments on exports, direct purchases abroad by residents, non-residents purchases in domestic territory, international transport margin, and output at basic prices.

\section{Empirical Estimation}

This section describes the construction of the variables from the WIOD database and following the methodology described in section 2. Following the description of the estimation procedure, we discussed the empirical findings.

\subsection{Estimation Strategy}

This paper uses the WIOT's to calculate value added trade shares, consumer price index from the World Economic Outlook (WEO) database as a measure of 
prices in local currency, and we also used OECD producer price index instead of GDP deflator or inflation index as a proxy for price measures. ${ }^{8}$ We took nominal bilateral exchange rates across countries during the sample period from UNCTAD Stats.

The value-added trade shares are calculated from the World Input-Output table, where each row shows the global use of respective sector's output in each country by sector, i.e., whether that product is used as an intermediate input by the industry or is used as a final good by consumers in each country. The column's indicates the total inputs from each countries, plus the value added (value added by labor and capital) in each country-sector, that are supplied to produce the total output of a product in each country. Then the value added is calculated following equation 4.1

$$
V=F(I-A)^{-1} C
$$

where $A$ is the matrix of intermediate inputs needed to produce one unit of output, $(I-A)^{-1}$ is known as Leontief inverse, which represents the gross output values that are generated in all stages of the production process of one unit of consumption. $F$ represents a diagonal matrix of value added to gross output ratios in all industries in all countries. The value-added exports of a country, $C$ counts the consumption to other countries in consideration. Although, this method can retrieve a value-added trade structure, but this method failed to define back-and-forth trade exclusively.

This paper follows Wang et al. (2013) (in equation 37) methodology to measure the back-and-forth nature of trade. ${ }^{9}$ They decomposed gross exports into domestic value-added absorbed abroad (DVA), value-added first exported but

\footnotetext{
${ }^{8}$ Estimation results for producer price index are not presented in this paper, however, interested person can send me email for that tables.

${ }^{9}$ Koopman et al. (2014) first provided an accounting framework to decompose total gross exports of a country into nine value-added and double counted components. Although, their accounting framework can define the back-and-forth nature of trade, but this famework is suitable for country level rather country-sector studies.
} 
eventually returned home (RDV), foreign value-added (FVA), and pure double counted terms (PDC). They further decomposed the DVA, FVA, and PDC into intermediate goods, intermediate goods re-exported to third countries as intermediate goods, and final goods. ${ }^{10}$

The econometric estimation is based on equation 3.8. For the regression purpose, we have considered the first difference of logarithm of the the valueadded export for a country. This study used domestic intermediate inputs those are exported in abroad and then returned back to home country as an intermediate goods as of our dependent variable. Similarly, price index and exchangerate variables are also transformed into first-difference of logarithms of the variable. ${ }^{11}$

Moreover, as a robustness check, we also estimated other models where dependent variables are intermediate goods returned home as final goods and value-added trade, and for sub-sample only for the manufacturing sectors. Apart from those, we also estimated the above mentioned models with $100 \%$ valueadded share to compare with our results.

\subsection{Estimation Results}

This section presents the empirical estimation results following the above-mentioned methodology. Section 4.2.1 presents the aggregated (pooled over sector and country) exchange rate pass-through along with sector-level estimations, while section 4.2.2 presents the trade elasticity calculated using equation 3.15.

\subsubsection{Exchange Rate Pass-Through}

The first column of table 1 presents ERPT for total value-added exports estimated for a pooled data. Table 1 shows the estimation results for ERPT and

\footnotetext{
${ }^{10}$ A detail decomposition of Wang et al. (2013) is given in appendix.

${ }^{11}$ Similar type of exercises also done by (Powers and Riker, 2013), they did it only from 13 Non-Petroleum sectors and only for 2000-2009 for selected countries.
} 
elasticity of substitution for different specifications of value-added exports. All the models presented in table 1 have common set of independent variables, i.e., domestic price index, value added share adjusted bilateral nominal exchange rates, and different combination of fixed effects as control measures. The first column of table 1 shows the ERPT estimator for total value added exports is 0.028 , i.e., a one percent increase in exchange rate (in another term, $1 \%$ depreciation of local currency) increases value added exports by 0.028 percent. Similarly, the second and the third columns show the ERPT estimator for value added as intermediate exports and domestic value added exports as intermediate goods are 0.022 and 0.021 , respectively. The elasticity of substitution is 1.175 , which is statistically significant and different from one.

Table 1: Exchange Rate Pass-Through (ERPT) and Elasticity of Substitution

\begin{tabular}{|c|c|c|c|c|c|c|c|c|c|}
\hline VARIABLES & texp & texpint & dva_int & $\mathrm{rdv}$ & rdv_int & rdv_fin & rdv_fin2 & fva & fva_int \\
\hline \multirow{2}{*}{$\operatorname{EoS}(\sigma)$} & 1.175 & 1.174 & 1.169 & 1.328 & 1.134 & 1.160 & 1.139 & 1.141 & 1.032 \\
\hline & $(0.043)$ & $(0.036)$ & $(0.034)$ & $(0.030)$ & $(0.019)$ & $(0.020)$ & $(0.017)$ & $(0.038)$ & $(0.026)$ \\
\hline \multirow{2}{*}{$\operatorname{ERPT}(\lambda)$} & 0.028 & 0.022 & 0.021 & $\begin{array}{l}0.002 \\
\end{array}$ & 0.009 & 0.006 & 0.009 & 0.028 & 0.006 \\
\hline & $(0.002)$ & $(0.002)$ & $(0.002)$ & $(0.000)$ & $(0.000)$ & $(0.000)$ & $(0.000)$ & $(0.002)$ & $(0.000)$ \\
\hline \multirow[t]{2}{*}{ Constant } & 0.1456 & 0.1145 & 0.1094 & 0.1012 & 0.0806 & 0.0993 & 0.0979 & 0.1333 & 0.0492 \\
\hline & $(0.038)$ & $(0.031)$ & $(0.030)$ & $(0.019)$ & $(0.020)$ & $(0.018)$ & $(0.018)$ & $(0.030)$ & $(0.018)$ \\
\hline Observations & 828,567 & 828,567 & 827,872 & 333,866 & 828,449 & 828,567 & 828,567 & 828,434 & 332,924 \\
\hline R-squared & 0.005 & 0.006 & 0.006 & 0.050 & 0.011 & 0.009 & 0.013 & 0.006 & 0.056 \\
\hline Year FE & Yes & Yes & Yes & $\begin{array}{l}\text { Yes } \\
\text { Y }\end{array}$ & Yes & Yes & Yes & Yes & Yes \\
\hline Exporter FE & Yes & Yes & Yes & Yes & Yes & Yes & Yes & Yes & Yes \\
\hline
\end{tabular}

Note: Robust standard errors are in parentheses. All these variables are statistically significant at $5 \%$ level. Here, rev, rev_int, rev_fin, and rev_fin2 stands for domestic value added returned home, domestic value added returned home as intermediate, domestic value added returned home as final goods, domestic value added returned home as final through third country, respectively. texp, texpint, dva_int, fva, and fav_int stands for value added exports, value added exports as intermediate, domestic value added exports as intermediates, foreign value added in domestic export, and foreign value added in domestic exports of intermediates, respectively.

In this paper, we are interested to see the effect of exchange rate change on value added exports that returned home. In table 1, column 4- 7 shows different 
specifications of value added exports that returned home as final or intermediate products. In column 4 , the dependent variable is domestic value added that returned home (RDV) and the ERPT estimate is 0.002 . This shows that a $1 \%$ increase (depreciation) in exchange rate passes through into the exports by 0.002 percent, which is much lower than the coefficient for gross value added exports. In column 5, its shows that domestic value added returned home as intermediate goods (RDV_INT), the ERPT estimate is 0.009 and ERPT estimate is 0.006 for the value added returned home as final goods (RDV_FIN). From table 1, it is also evident that elasticity of substitution for RDV, RDV_INT, and RDV_FIN are also significantly different from one and mostly greater than one. This table (table 1) shows a significant variation in ERPT across different specification of value added exports. The heterogeneity of ERPT estimate supports our claim that under the back-and-forth production structure, exchange rate becomes less effective as an automatic stabilizer.

Table 2 presents exchange rate pass-through and elasticity of substitution for each of the sectors using different measures of value added exports as dependent variable following equation (3.8). It is evident from the table (table 2) that there is significant heterogeneity in ERPT across sectors: interestingly, some of the sectors have a negative coefficient for ERPT and are significantly different from zero. This estimation also suggests that there is no evidence of complete pass-through. The median pass-through is 0.008 for value added exports. We found that median pass-through for manufacturing sectors are 0.016 and for services sectors are -0.007 . In this estmiation, we also included country and time fixed effects. Our estimated exchange rate pass-throughs are significantly lower compared to Powers and Riker (2013), Brun-Aguerre et al. (2012) and Campa and Goldberg (2005). We also found that there is substantial heterogeneity across sectors in terms of pass-through rates (see 5), where service sectors show negative ERPT that can be for the increasing embadement of ser- 
Table 2: Summary Statistics of ERPT and elasticity of substitution by sectors

\begin{tabular}{|c|c|c|c|c|c|c|c|c|c|c|c|c|}
\hline \multirow[b]{2}{*}{ VARIABLES } & \multicolumn{2}{|c|}{$\mathrm{rdv}$} & \multicolumn{2}{|c|}{ rdv_int } & \multicolumn{2}{|c|}{ rdv_fin } & \multicolumn{2}{|c|}{ dva_int } & \multicolumn{2}{|c|}{ texp } & \multicolumn{2}{|c|}{ texp_int } \\
\hline & $\sigma$ & $\lambda$ & $\sigma$ & $\lambda$ & $\sigma$ & $\lambda$ & $\sigma$ & $\lambda$ & $\sigma$ & $\lambda$ & $\sigma$ & $\lambda$ \\
\hline Median & 1.318 & 0.004 & 1.142 & 0.003 & 1.098 & -0.001 & 1.144 & 0.001 & 1.142 & 0.008 & 1.154 & 0.004 \\
\hline Average & 1.412 & 0.026 & 1.133 & 0.233 & 1.159 & 0.033 & 1.167 & 0.165 & 1.173 & 0.090 & 1.173 & 0.155 \\
\hline Manufacturing & 1.365 & 0.137 & 1.146 & 0.056 & 1.227 & 0.064 & 1.188 & 0.156 & 1.250 & 0.016 & 1.197 & 0.204 \\
\hline Services & 1.404 & -0.048 & 1.122 & 0.056 & 1.140 & -0.004 & 1.151 & 0.185 & 1.114 & -0.007 & 1.153 & 0.128 \\
\hline
\end{tabular}

vice into manufacturing exports.

Table 4 shows the comparision of ERPT and elasticity of substitution estimates between value added exports and $100 \%$ domestic value added exports. It also evident that for a $100 \%$ domestic value addition, median pass-through is 0.732, which is also similar to Powers and Riker (2013). This estimation results are very high compared to the estimates using domestic value added exports that returned home, which suggests that when back-and-forth trade is happening to produce a single product then pass-through rate is minimum.

The point estimates for the elasticity of substitution suggests that elasticities are significantly different from one, though for a few of the sectors value of elasticities is less than one. The median value for elasticities of substitution ranging from 1.098 , to 1.318 , for manufacturing sectors this value ranges from 1.146 to 1.365 and for service sectors 1.114 to 1.404 . These median values of elasticities of substitution are similar to Powers and Riker (2013).

Figure (5) summarizes the relationship between exchange rate pass-through coefficients and share of domestic value added that returned home (RDV) by country. From figure 5, it is evident that, there are significant heterogeneity across countries in terms of ERPT coefficients and also RDV. Although most of the countries have a very small ERPT for return DVA, countries with higher integration with the global market in the production chain have a higher share of RDV and lower value of ERPT. For example, except China, developed countries have higher share in global production chain and lower value of ERPT 
Figure 5: ERPT and share of DVA returned home by countries

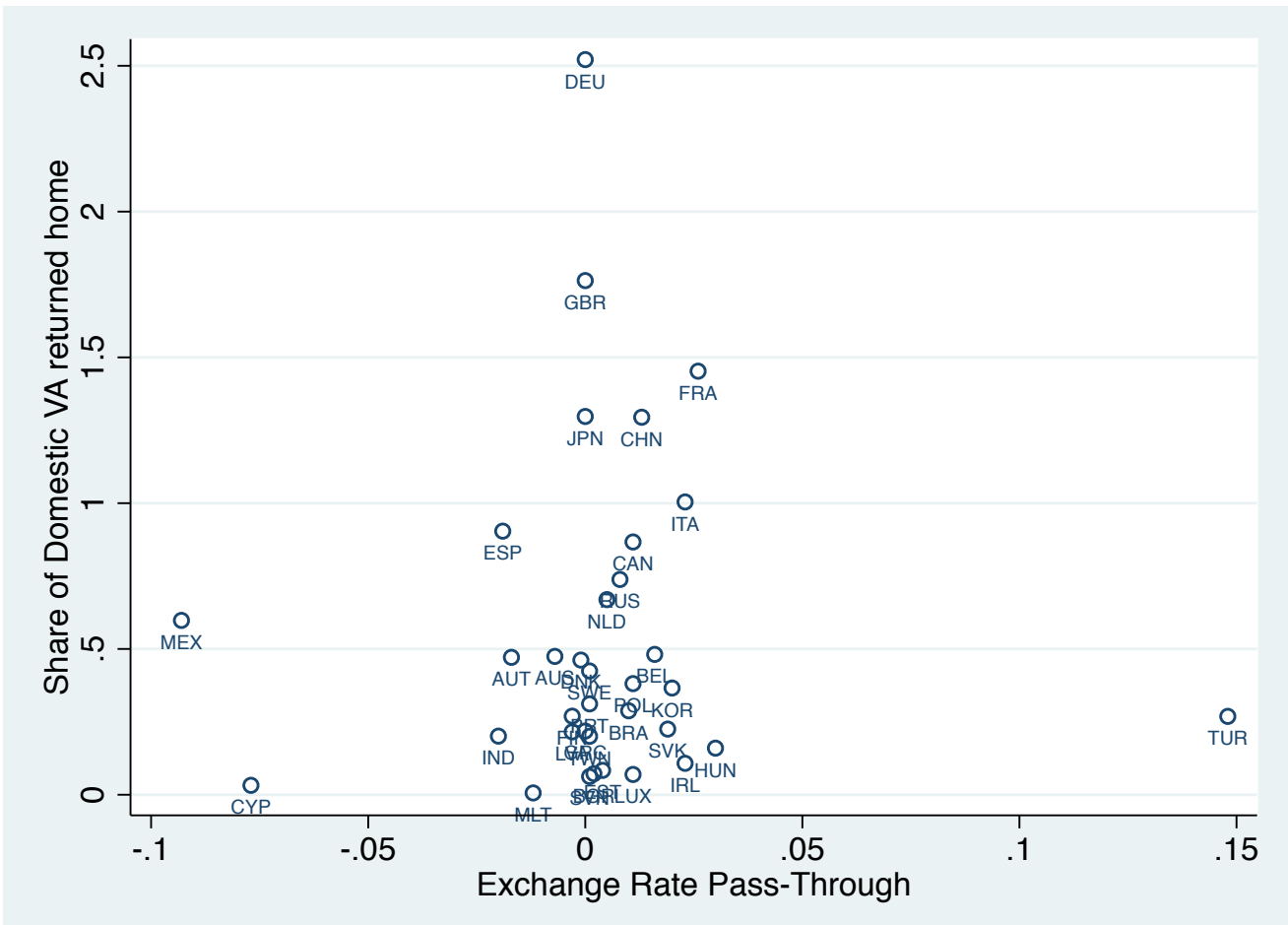

coefficient. Similarly, developing countries, like China, India or Mexico, have a smaller share of RDV and ERPT with close to zero (Mexico has a negative ERPT coefficient). This relation supports our claim that countries with higher integration in back-and-forth trade structure have a lower pass-through effect. We found that our estimated coefficients vary between -0.1 to 0.18 , which is significantly lower than Campa and Mínguez (2006) and Gaulier et al. (2008). ${ }^{12}$.

Figure (6) summarizes the relation between exchange rate pass-through coefficients and share of domestic value added that returned home (RDV) by sector. This figure (6) illustrates that there is a lot of heterogeneity in ERPT across sectors. The first segment shows that within manufacturing sectors, ERPT vary significantly: apparel and textile, manufacturing, electronics sectors have lower ERPT. The second segment shows that within service sectors, ERPT vary less than manufacturing. This result also supports the fact that manufacturing sector's production is embodied with services .

\footnotetext{
${ }^{12}$ Campa and Mínguez (2006) found a ERPT coefficient of 0.317 for EURO countries, while Gaulier et al. (2008) found that weight average of median pass-through is 0.128 across countries
} 
Figure 6: ERPT and share of DVA returned home by sectors

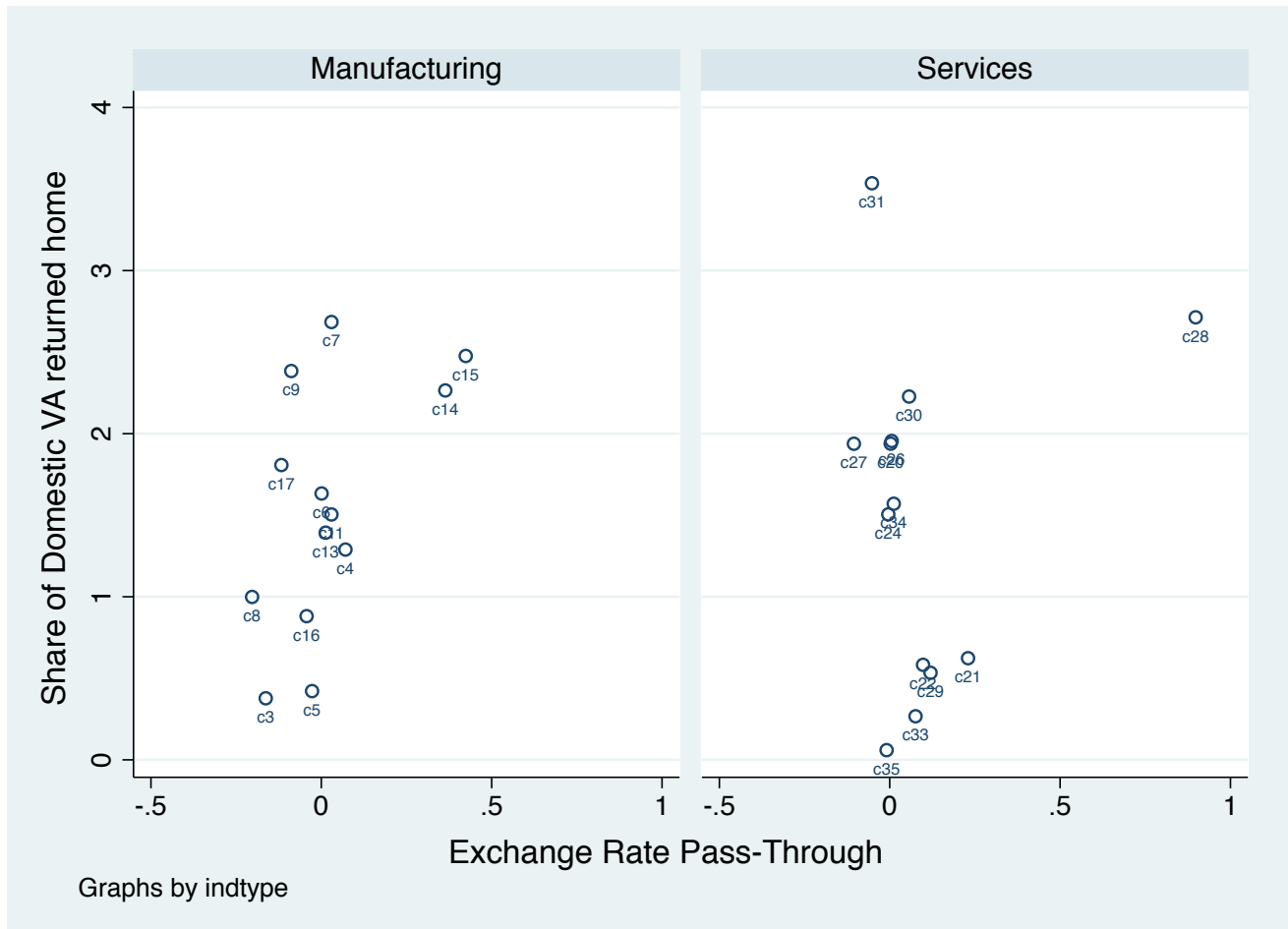

Table 8 and table 9 show the point estimation regression coefficients for all the sectors and all countries (full sample) for gross value added exports and $100 \%$ domestic value added. From table 8, we can find the coefficients for regressions among the 35 sectors, 17 sectors have statistically significant coefficients on a $1 \%$ or $5 \%$ level. Table 9 presents the point estimation regression coefficients for all sectors and all countries for $100 \%$ domestically value addition in their export items. Comparing both foreign value-added and 100\% domestic value addition, both have 17 sectors as statistically significant, but sectors are different in these two sectors.

\subsubsection{Trade Elasticity}

Table 3 presents the estimates of elasticity of substitution for the USA in 2011 for few selected countries countries and sectors. We calculated the trade elasticity using equation 10 , and the $\sigma$ and $\lambda$ coefficient are coming from regression estimation. In the first panel of table 3 shows the elasticity of substitution 
for agriculture, hunting, forestry and fisheries for Brazil, Canada, China, India, Japan, and Mexico. For example, a 10\% increase in the nominal exchange rate of Renminbi or the price of Renminbi ( $10 \%$ depreciation of renminbi relative to USD) will increase the value of China's export of the agricultural, forestry and fisheries by $2.3 \%$ of which we decomposed into own price effect and price index effect. The own price effect is negative and it shows that $0.19 \%$ decreases the exports from China to the USA and this negative effect is eliminated by the positive price index effect which increases exports by $2.5 \%$. Similarly, for the country Brazil, a 10\% depreciation of Brazil real will increase the export from Brazil to the USA by about $0.203 \%$, among which own price effect is close to insignificant amount, $0.01 \%$, and relatively strong positive effect of price index effect, $0.23 \%$. From the first row of panel one in table 3 , also confirms that there is substantial heterogeneity across countries in trade elasticity.

In the second panel of table 3 , we can see that with a $10 \%$ depreciation of renminbi will increase the export from China to the USA by $0.51 \%$, on the other hand, with a 10\% depreciation of Canadian dollar to USD will increase export of food, and beverages from Canada to the USA by $7.64 \%$. For a similar depreciation of Japanese Yen will increase export from Japan to the United States by $0.078 \%$, for India it will increase in export from India to the United States by $0.051 \%$. These results confirms that for a particular sector, higher trade elasticity value associated with a country implies a higher domestic value-added content in their exports.

Panel three in table 3 shows that with a 10\% depreciation of Mexican peso to the USD will increase exports of textile and textile products to the United States by $17.2 \%$, and most of this positive export changes is driven by the larger positive price index effect compared to vary small negative own price index effect. For a 10\% depreciation of Indian rupee, exports of textile and textile products from India to the United States will increase by 3.17\%. 
Table 3: Trade Elasticity for selected Sectors and for selected countries to USA in 2011

\begin{tabular}{|c|c|c|c|c|c|c|}
\hline \multicolumn{7}{|c|}{ Panel One: Trade Elasticity for Agriculture, Hunting, Forestry and Fishing for 2011 for USA } \\
\hline & BRA & CAN & $\mathrm{CHN}$ & IND & JPN & MEX \\
\hline Trade Elasticity with Value added data & 0.0203 & 0.1409 & 0.2309 & 0.0153 & 0.0069 & 0.1598 \\
\hline Own price Effect & -0.0019 & -0.0191 & -0.0191 & -0.0007 & -0.0008 & -0.0091 \\
\hline Price Index Effect & 0.0222 & 0.1600 & 0.2500 & 0.0160 & 0.0077 & 0.1690 \\
\hline \multirow[t]{2}{*}{ Ratio of Price Index Effect to Own price effect } & -0.0863 & -0.1195 & -0.0765 & -0.0423 & -0.1061 & -0.0540 \\
\hline & \multicolumn{6}{|c|}{ Panel Two: Trade Elasticity for Food, Beverages and Tobacco for 2011 for USA } \\
\hline Trade Elasticity with Value added data & 0.0203 & 0.7637 & 0.0510 & 0.0510 & 0.0077 & 0.3277 \\
\hline Own price Effect & -0.0019 & -0.0309 & -0.0028 & -0.0017 & -0.0003 & -0.0099 \\
\hline Price Index Effect & 0.0222 & 0.7946 & 0.0538 & 0.0527 & 0.0080 & 0.3375 \\
\hline \multirow[t]{2}{*}{ Ratio of Price Index Effect to Own price effect } & -0.0863 & -0.0389 & -0.0521 & -0.0322 & -0.0397 & -0.0292 \\
\hline & & & & & & \\
\hline \multicolumn{7}{|c|}{ Panel Three: Trade Elasticity for Textiles and Textile Products for 2011 for USA } \\
\hline Trade Elasticity with Value added data & 0.0182 & 0.9338 & 0.2655 & 0.3173 & 0.0101 & 1.7287 \\
\hline Own price Effect & -0.0008 & -0.0441 & -0.0209 & -0.0120 & -0.0014 & -0.0732 \\
\hline Price Index Effect & 0.0189 & 0.9779 & 0.2864 & 0.3292 & 0.0115 & 1.8018 \\
\hline \multirow[t]{2}{*}{ Ratio of Price Index Effect to Own price effect } & -0.0398 & -0.0451 & -0.0731 & -0.0364 & -0.1253 & -0.0406 \\
\hline & & & & & & \\
\hline \multicolumn{7}{|c|}{ Panel Four: Trade Elasticity for Machinery for 2011 for USA } \\
\hline Trade Elasticity with Value added data & 0.0082 & 0.0494 & 0.2016 & 0.0053 & 0.0143 & 0.1436 \\
\hline Own price Effect & -0.0003 & -0.0032 & -0.0006 & -0.0002 & -0.0006 & -0.0057 \\
\hline Price Index Effect & 0.0085 & 0.0526 & 0.2022 & 0.0055 & 0.0149 & 0.1493 \\
\hline Ratio of Price Index Effect to Own price effect & -0.0326 & -0.0605 & -0.0030 & -0.0425 & -0.0419 & -0.0384 \\
\hline
\end{tabular}


Likewise, panel four in table 3 presents trade elasticity for the sector of machinery and related equipment. Column 4 shows that with a 10\% depreciation of renminbi to USD will increase exports of machinery from China to the USA by $2.01 \%$, while for a similar depreciation of Mexican peso will increase export for machinery from Mexico to the United States by $1.4 \%$.

\section{Conclusion}

This paper estimates the effect of nominal exchange rate fluctuations on the value of imports of manufacturing and services sectors in the OECD and some developing countries using a structural model of back-and-forth production and value- added trade decomposed from gross trade flows. This paper contributes to the literature of international finance and trade by examining a new production structure, where inputs shared among countries in several stages. The empirical estimation for bilateral trade by sectors uses data from the World Input Output Database (WIOD). The database contains time series data on the international sourcing of intermediate inputs and final goods in 35 sectors across 40 countries (27 EU and 13 other major countries) for the period of 19952011. The WIOD database also contains data on sectoral trade, domestic expenditure, and final expenditure and sectoral value added (labor and capital) in production. From the input-output table, we estimate the sources of value added in final goods traded and consumed in the world.

From the empirical estimation, we found that the median pass-through rate is 0.119 , while the pass-through rate for the manufacturing sector is 0.112 and the pass-through rate for the service sector is -0.01 . This paper decomposes trade elasticity into two parts: own price and price index effect. Own price effects capture the cost increase due to increase in raw materials price from an exchange rate shock. We found that there is a substantial heterogeneity both in own price and cross-price elasticities across sectors and across countries. For ex- 
ample, we find that for a $10 \%$ increase in the nominal exchange rate of Renminbi to USD (10\% depreciation of Renminbi relative to USD) will increase China's export of agricultural, forestry and fisheries by $2.3 \%$. Further, we found that due to negative effect of own price effect, export decreased by $0.19 \%$, while positive price effect export increases by $2.5 \%$.

We empirically tested our structured model, which incorporates back-andforth production structure and value-added trade. From our estimation result, it is evident that trade elasticity estimates without considering the intermediate inputs sharing across borders are systematically overstated. The estimates also validated the importance of price index effect in exports from most of the countries to their destination markets.

\section{References}

Amiti, M., Itskhoki, O., and Konings, J. (2014). Importers, exporters, and exchange rate disconnect. American Economic Review, 104(7):1942-1978.

Armington, P. (1969). A theory of demand for products distinguished by place of production. IMF Staff Papers, 16:159-176.

Baldwin, R. and Lopez-Gonzalez, J. (2013). Supply-chain trade: A portrait of global patterns and several testable hypotheses. Working Paper 18957, National Bureau of Economic Research.

Bayoumi, T., Saito, M., and Turunen, J. (2013). Measuring competitiveness: Trade in goods or tasks? IMF Working Paper, May 2013(WP/13/100).

Bayoumi, T. A., Lee, J., and Jayanthi, S. (2006). New rates from new weights. IMF Staff Papers, 53(2).

Bems, R. (2014). Intermediate inputs, external rebalancing and relative price adjustment. Journal of International Economics.

Bems, R. and Johnson, R. C. (2012). Value-added exchange rates. Technical Report WP 18498, National Bureau of Economic Research.

Bems, R. and Johnson, R. C. (2015). Demand for value added and value-added exchange rates. NBER Working Paper, (w21070). 
Bems, R., Johnson, R. C., and Yi, K.-M. (2011). Vertical linkages and the collapse of global trade. The American Economic Review, pages 308-312.

Berka, M., Devereux, M. B., and Engel, C. (2014). Real exchange rates and sectoral productivity in the eurozone. Working Paper 20510, National Bureau of Economic Research.

Berman, N., Martin, P., and Mayer, T. (2012). How do different exporters react to exchange rate changes? The Quarterly Journal of Economics, 127(1):437-492.

Borchert, I., Gootiiz, B., and Mattoo, A. (2014). Policy barriers to international trade in services: evidence from a new database. The World Bank Economic Review, 28(1):162-188.

Brun-Aguerre, R., Fuertes, A.-M., and Phylaktis, K. (2012). Exchange rate passthrough into import prices revisited: what drives it? Journal of International Money and Finance, 31(4):818-844.

Burstein, A. and Gopinath, G. (2014). International prices and exchange rates. Handbook of International Economics,, 4:391-451.

Bussiere, M. (2013). Exchange rate pass-through to trade prices: The role of nonlinearities and asymmetries. Oxford Bulletin of Economics and Statistics, 75(5):731-758.

Bussière, M., Delle Chiaie, S., and Peltonen, T. A. (2014). Exchange rate passthrough in the global economy: The role of emerging market economies. IMF Economic Review, 62(1):146-178.

Campa, J. M. and Goldberg, L. S. (2005). Exchange rate pass-through into import prices. Review of Economics and Statistics, 87(4):679-690.

Campa, J. M. and Mínguez, J. M. G. (2006). Differences in exchange rate passthrough in the euro area. European Economic Review, 50(1):121-145.

Cassel, G. (1921). The world's monetary problems; two memoranda. Constable \& Company limited.

Cheung, Y.-W., Chinn, M. D., and Qian, X. (2012). Are chinese trade flows different? Journal of International Money and Finance, 31(8):2127-2146.

Chinn, M. D. (2006). A primer on real effective exchange rates: determinants, overvaluation, trade flows and competitive devaluation. Open economies review, 17(1):115-143. 
Chungy, W. (2012). Back-and-forth trade and endogenous exchange rate passthrough.

Daudin, G., Rifflart, C., and Schweisguth, D. (2011). Who produces for whom in the world economy? Canadian Journal of Economics/Revue canadienne d'économique, 44(4):1403-1437.

Di Giovanni, J. and Levchenko, A. A. (2010). Putting the parts together: Trade, vertical linkages, and business cycle comovement. American Economic Journal: Macroeconomics, 2(2):95-124.

Feenstra, R. C., Luck, P. A., Obstfeld, M., and Russ, K. N. (2014). In search of the armington elasticity. Working Paper 20063, National Bureau of Economic Research.

Gagnon, E., Mandel, B. R., and Vigfusson, R. J. (2014). Missing import price changes and low exchange rate pass-through. American Economic Journal: Macroeconomics, 6(2):156-206.

Gaulier, G., Lahrèche-Révil, A., and Méjean, I. (2008). Exchange-rate passthrough at the product level. Canadian Journal of Economics/Revue canadienne d'économique, 41(2):425-449.

Gawande, K., Hoekman, B., and Cui, Y. (2014). Global supply chains and trade policy responses to the 2008 crisis. The World Bank Economic Review, page lht040.

Ghosh, A. (2009). Implications of production sharing on exchange rate passthrough. International Journal of Finance E Economics, 14(4):334-345.

Ghosh, A. (2013). Cross-border production sharing and exchange-rate sensitivity of mexico's trade balance. The Journal of International Trade $\mathcal{E}$ Economic Development, 22(2):281-297.

Goldberg, L. S. (2004). Industry-specific exchange rates for the united states. Federal Reserve Bank of New York Economic Policy Review, 10(1).

Goldberg, L. S. and Campa, J. M. (2010). The sensitivity of the cpi to exchange rates: Distribution margins, imported inputs, and trade exposure. The Review of Economics and Statistics, 92(2):392-407.

Gust, C., Leduc, S., and Vigfusson, R. (2010). Trade integration, competition, and the decline in exchange-rate pass-through. Journal of Monetary Economics, 57(3):309-324. 
Hummels, D., Ishii, J., and Yi, K.-M. (2001). The nature and growth of vertical specialization in world trade. Journal of international Economics, 54(1):75-96.

Ito, K. and Shimizu, J. (2014). Industry-level competitiveness, productivity, and effective exchange rates in east asia. Discussion Papers (by fiscal year), 2013:2012.

Jensen, J. B., Quinn, D. P., and Weymouth, S. (2013). Global supply chains, currency undervaluation, and firm protectionist demands. Working Paper 19239, National Bureau of Economic Research.

Johnson, R. C. (2014). Five facts about value-added exports and implications for macroeconomics and trade research. The Journal of Economic Perspectives, 28(2):119-142.

Johnson, R. C. and Noguera, G. (2012). Accounting for intermediates: Production sharing and trade in value added. Journal of International Economics, 86(2):224-236.

Jones, L., Powers, W., and Ubee, R. (2013). Making global value chain research more accessible. US International Trade Commission Office of Economics Working Paper, (2013-10A).

Koopman, R., Wang, Z., and Wei, S.-J. (2008). How much of chinese exports is really made in china? assessing domestic value-added when processing trade is pervasive. Technical report, National Bureau of Economic Research.

Koopman, R., Wang, Z., and Wei, S.-J. (2012). Estimating domestic content in exports when processing trade is pervasive. Journal of Development Economics, 99(1):178-189.

Koopman, R., Wang, Z., and Wei, S.-J. (2014). Tracing value-added and double counting in gross exports. American Economic Review, 104(2):459-494.

Marazzi, M., Sheets, N., Vigfusson, R., Faust, J., Gagnon, J., Marquez, J., Martin, R., Reeve, T., Rogers, J., et al. (2005). Exchange rate pass-through to us import prices: some new evidence. Board of Governors of the Federal Reserve System, International Finance, (DP 833).

Mattoo, A., Wang, Z., and Wei, S.-J. (2013). Trade in value added: Developing new measures of cross-border trade. World Bank Publications. 
Patel, N., Wang, Z., and Wei, S.-J. (2014). Global value chains and effective exchange rates at the country-sector level. Working Paper 20236, National Bureau of Economic Research.

Powers, W. and Riker, D. (2013). Exchange rate pass-through in global value chains: The effects of upstream suppliers. Technical Report 2013-02B.

Powers, W. and Riker, D. (2015). The effect of exchange rates on the costs of exporters when inputs are denominated in foreign currencies. The International Trade Journal, 29(1):3-18.

Purfield, C. and Rosenberg, C. B. (2010). Adjustment under a currency peg: Estonia, latvia and lithuania during the global financial crisis 2008-09. IMF Working Papers, pages 1-34.

Rodríguez-López, J. A. (2011). Prices and exchange rates: A theory of disconnect. The Review of Economic Studies, pages 1135-1177.

Rogoff, K. (2005). Rethinking exchange rate competitiveness. The Global Competitiveness Report, 2006:99-105.

Saito, M., Ruta, M., and Turunen, J. (2013). Trade interconnectedness: The world with global value chain. Policy paper, IMF Policy Paper.

Song, S. (2014). Exchange rate challenges, flexible intra-firm adjustments, and subsidiary longevity. Journal of World Business.

Stehrer, R., Foster, N., and de Vries, G. (2010). Value added and factors in trade: A comprehensive approach. Dynamics, (67).

Thorbecke, W. and Smith, G. (2010). How would an appreciation of the renminbi and other east asian currencies affect china's exports? Review of International Economics, 18(1):95-108.

Timmer, M. P., Dietzenbacher, H., Los, B., and Robert Stehrer, G. J. (2014a). The World Input-Output Database: Content, Concepts and Applications.

Timmer, M. P., Erumban, A. A., Los, B., Stehrer, R., and de Vries, G. J. (2014b). Slicing up global value chains. The Journal of Economic Perspectives, 28(2):99_ 118.

Wang, Z., Wei, S.-J., and Zhu, K. (2013). Quantifying international production sharing at the bilateral and sector levels. Working Paper 19677, National Bureau of Economic Research. 
Yi, K.-M. (2003). Can vertical specialization explain the growth of world trade? Journal of political Economy, 111(1):52-102. 


\section{A Decomposition of Gross exports into 9 parts by (Wang et al., 2013)}

\section{A.1 Gross exports of 2-country}

Let assume that there are 2 countries (Home and Foreign) in this hypothetical world, where each country produces goods in $\mathrm{N}$ tradable industries. Goods in each sector can be consumed directly or used as intermediate inputs, and each country exports both intermediate and final goods. The gross output produced by country $\mathrm{h}$ must be used as either an intermediate good or a final good at home or foreign country:

$$
X^{h}=A^{h h} X^{h}+Y^{h h}+A^{h f} X^{f}+Y^{h f} ;\{h, f\}=\{1,2\}
$$

Where $X^{h}$ is the $(N * 1)$ gross output vector of country $h, Y^{h f}$ is the $(N * 1)$ final demand vector that gives demand in country $f$ for final goods produced in $h . A^{h f}$ is the $(N * N)$ IO coefficient matrix that shows the intermediate used in $f$ of goods produced in $h$. The intra-country input output representation of the two-country production and trade procedure follows the following structure:

$$
\begin{array}{r}
{\left[\begin{array}{l}
X^{h} \\
X^{f}
\end{array}\right]=\left[\begin{array}{ll}
A^{h h} & A^{h f} \\
A^{f h} & A^{f f}
\end{array}\right]\left[\begin{array}{l}
X^{h} \\
X^{f}
\end{array}\right]+\left[\begin{array}{l}
Y^{h h}+Y^{h f} \\
Y^{f h}+Y^{f f}
\end{array}\right]} \\
{\left[\begin{array}{l}
X^{h} \\
X^{f}
\end{array}\right]=\left[\begin{array}{cc}
I-A^{h h} & -A^{h f} \\
-A^{f h} & I-A^{f f}
\end{array}\right]^{-1}\left[\begin{array}{l}
Y^{h h}+Y^{h f} \\
Y^{f h}+Y^{f f}
\end{array}\right]} \\
=\left[\begin{array}{ll}
B^{h h} & B^{h f} \\
B^{f h} & B^{f f}
\end{array}\right]\left[\begin{array}{l}
Y^{h} \\
Y^{f}
\end{array}\right]
\end{array}
$$

Here $B^{h f}$ denotes the $(N * N)$ matrix, which is known as the Leontief inverse. This bloc matrix shows the total requirement for the gross output production in country $h$ due to one unit increase in the final demand in country $f . Y^{h}$ is an $\left(\mathrm{N}^{*} 1\right)$ vector of country $h^{\prime}$ s final goods used globally: domestic use $\left(Y^{h h}\right)$ and export to foreign country $\left(Y^{h f}\right)$.

\section{A.2 2-country 2-sector}

Let consider the two-country have only two sectors. The gross exports of Country $h$ can be decomposed into two parts: final goods exports and intermediate goods exports based on the following accounting identity: 


$$
E^{h f}=\left[\begin{array}{c}
e_{1}^{h f} \\
e_{2}^{h f}
\end{array}\right]=\left[\begin{array}{l}
y_{1}^{h f} \\
y_{2}^{h f}
\end{array}\right]+\left[\begin{array}{ll}
a_{11}^{h f} & a_{12}^{h f} \\
a_{21}^{h f} & a_{22}^{h f}
\end{array}\right]\left[\begin{array}{l}
x_{1}^{f} \\
x_{2}^{f}
\end{array}\right]
$$

The gross output of Country $f$ can be decomposed into the following four components according to where they are finally absorbed:

$$
\begin{aligned}
X^{r} & =\left[\begin{array}{l}
x_{1}^{r} \\
x_{2}^{r}
\end{array}\right]=\left[\begin{array}{ll}
b_{11}^{r s} & b_{12}^{r s} \\
b_{21}^{r s} & b_{21}^{r s}
\end{array}\right]\left[\begin{array}{l}
y_{1}^{r r}+y_{1}^{r s} \\
y_{2}^{r r}+y_{2}^{r r}
\end{array}\right]+\left[\begin{array}{ll}
b_{11}^{r r} & b_{12}^{r r} \\
b_{21}^{r r} & b_{21}^{r r}
\end{array}\right]\left[\begin{array}{l}
y_{1}^{r r}+y_{1}^{r s} \\
y_{2}^{r r}+y_{2}^{r r}
\end{array}\right] \\
& =\left[\begin{array}{ll}
b_{11}^{r r} & b_{12}^{r r} \\
b_{21}^{r r} & b_{21}^{r r}
\end{array}\right]\left[\begin{array}{l}
y_{1}^{r r} \\
y_{2}^{r r}
\end{array}\right]+\left[\begin{array}{ll}
b_{11}^{r r} & b_{12}^{r r} \\
b_{21}^{r r} & b_{21}^{r r}
\end{array}\right]\left[\begin{array}{l}
y_{1}^{r s} \\
y_{2}^{r s}
\end{array}\right]+\left[\begin{array}{ll}
b_{11}^{r r} & b_{12}^{r r} \\
b_{21}^{r r} & b_{21}^{r r}
\end{array}\right]\left[\begin{array}{l}
y_{1}^{s r} \\
y_{2}^{s r}
\end{array}\right]
\end{aligned}
$$

Insert equation (A.4) into the last term of equation (A.3), we can decompose Country $h$ 's gross intermediate goods export according to where they are absorbed as:

$$
\begin{aligned}
& A^{h f} X^{f}=\left[\begin{array}{ll}
a_{11}^{h f} & a_{12}^{h f} \\
a_{21}^{h f} & a_{22}^{h f}
\end{array}\right]\left[\begin{array}{l}
x_{1}^{f} \\
x_{2}^{f}
\end{array}\right]=\left[\begin{array}{ll}
a_{11}^{h f} & a_{12}^{h f} \\
a_{21}^{h f} & a_{22}^{h f}
\end{array}\right]\left[\begin{array}{ll}
b_{11}^{f f} & b_{12}^{f f} \\
b_{21}^{f f} & b_{22}^{f f}
\end{array}\right]\left[\begin{array}{l}
y_{1}^{f f} \\
y_{2}^{f f}
\end{array}\right]+ \\
& {\left[\begin{array}{ll}
a_{11}^{h f} & a_{12}^{h f} \\
a_{21}^{h f} & a_{22}^{h f}
\end{array}\right]\left[\begin{array}{ll}
b_{11}^{f f} & b_{12}^{f f} \\
b_{21}^{f f} & b_{22}^{f f}
\end{array}\right]\left[\begin{array}{l}
y_{1}^{h f} \\
y_{2}^{h f}
\end{array}\right]+\left[\begin{array}{ll}
a_{11}^{h f} & a_{12}^{h f} \\
a_{21}^{h f} & a_{22}^{h f}
\end{array}\right]\left[\begin{array}{ll}
b_{11}^{h f} & b_{12}^{h f} \\
b_{21}^{h f} & b_{22}^{h f}
\end{array}\right]\left[\begin{array}{l}
y_{1}^{h h} \\
y_{2}^{h h}
\end{array}\right]+} \\
& {\left[\begin{array}{ll}
a_{11}^{h f} & a_{12}^{h f} \\
a_{21}^{h f} & a_{22}^{h f}
\end{array}\right]\left[\begin{array}{ll}
b_{11}^{h f} & b_{12}^{h f} \\
b_{21}^{h f} & b_{22}^{h f}
\end{array}\right]\left[\begin{array}{c}
y_{1}^{h f} \\
y_{2}^{h f}
\end{array}\right]}
\end{aligned}
$$

The equation A.5 presents 2-country, 2-sector exports by their use. The first part of equation A.5 shows the amount of country $h$ 's intermediate goods exports utilized by country $f$ in their final goods production, which is finally consumed by country $f$. The second part shows the amount of country $h$ 's intermediate goods exports to country $f^{\prime}$ 's final goods production, which then return to country $h$. The third part shows the amount of intermediate goods exports by country $h$ to country $f$ to produce intermediate goods, which then returned to country $h$ to make final goods for home domestic consumption. The last part shows the amount of country $h$ 's intermediate goods exports used by country $f$ to produce intermediate goods and exported back to country $h$ to produce final goods, which finally exported to country $f$ as final goods.

With some more algebraic manipulation, accounting identity and Leontief inversion, We obtain country $h$ 's gross exports as follows: 


$$
\begin{aligned}
& E^{h f}=\left[\begin{array}{c}
e_{1}^{h f} \\
e_{2}^{h f}
\end{array}\right]=\left[\begin{array}{l}
y_{1}^{h f} \\
y_{2}^{h f}
\end{array}\right]+\left[\begin{array}{ll}
a_{11}^{h f} & a_{12}^{h f} \\
a_{21}^{h f} & a_{22}^{h f}
\end{array}\right]\left[\begin{array}{l}
x_{1}^{f} \\
x_{2}^{f}
\end{array}\right] \\
& =\left[\begin{array}{l}
v_{1}^{h} b_{11}^{h h}+v_{2}^{h} b_{21}^{h h} \\
v_{2}^{h} b_{12}^{h h}+v_{2}^{h} b_{22}^{h h}
\end{array}\right] \#\left[\begin{array}{c}
y_{1}^{h f} \\
y_{2}^{h f}
\end{array}\right]+\left[\begin{array}{l}
v_{1}^{h} b_{11}^{h h}+v_{2}^{h} b_{21}^{h h} \\
v_{2}^{h} b_{12}^{h h}+v_{2}^{h} b_{22}^{h h}
\end{array}\right] \#\left(\left[\begin{array}{ll}
a_{11}^{h f} & a_{12}^{h f} \\
a_{21}^{h f} & a_{22}^{h f}
\end{array}\right]\left[\begin{array}{ll}
b_{11}^{f f} & b_{12}^{f f} \\
b_{21}^{f f} & b_{22}^{f f}
\end{array}\right]\left[\begin{array}{c}
y_{1}^{f f} \\
y_{2}^{f f}
\end{array}\right]\right) \\
& +\left[\begin{array}{l}
v_{1}^{h} l_{11}^{h h}+v_{2}^{h} l_{21}^{h h} \\
v_{2}^{h} l_{12}^{h h}+v_{2}^{h} l_{22}^{h h}
\end{array}\right] \#\left(\left[\begin{array}{ll}
a_{11}^{h f} & a_{12}^{h f} \\
a_{21}^{h f} & a_{22}^{h f}
\end{array}\right]\left[\begin{array}{ll}
b_{11}^{f f} & b_{12}^{f f} \\
b_{21}^{f f} & b_{22}^{f f}
\end{array}\right]\left[\begin{array}{l}
y_{1}^{f h} \\
y_{2}^{f h}
\end{array}\right]\right) \\
& +\left[\begin{array}{l}
v_{1}^{h} l_{11}^{h h}+v_{2}^{h} l_{21}^{h h} \\
v_{2}^{h} l_{12}^{h h}+v_{2}^{h} l_{22}^{h h}
\end{array}\right] \#\left(\left[\begin{array}{ll}
a_{11}^{h f} & a_{12}^{h f} \\
a_{21}^{h f} & a_{22}^{h f}
\end{array}\right]\left[\begin{array}{ll}
b_{11}^{f h} & b_{12}^{f h} \\
b_{21}^{f h} & b_{22}^{f h}
\end{array}\right]\left[\begin{array}{l}
y_{1}^{h h} \\
y_{2}^{h h}
\end{array}\right]\right) \\
& {\left[\begin{array}{l}
v_{1}^{h} l_{11}^{h h}+v_{2}^{h} l_{21}^{h h} \\
v_{2}^{h} l_{12}^{h h}+v_{2}^{h} l_{22}^{h h}
\end{array}\right] \#\left(\left[\begin{array}{ll}
a_{11}^{h f} & a_{12}^{h f} \\
a_{21}^{h f} & a_{22}^{h f}
\end{array}\right]\left[\begin{array}{ll}
b_{11}^{f h} & b_{12}^{f h} \\
b_{21}^{f h} & b_{22}^{f h}
\end{array}\right]\left[\begin{array}{c}
y_{1}^{h f} \\
y_{2}^{h f}
\end{array}\right]\right)} \\
& \left(\left[\begin{array}{l}
v_{1}^{h} b_{11}^{h h}+v_{2}^{h} b_{21}^{h h} \\
v_{2}^{h} b_{12}^{h h}+v_{2}^{h} b_{22}^{h h}
\end{array}\right]-\left[\begin{array}{l}
v_{1}^{h} l_{11}^{h h}+v_{2}^{h} l_{21}^{h h} \\
v_{2}^{h} l_{12}^{h h}+v_{2}^{h} l_{22}^{h h}
\end{array}\right]\right) \#\left(\left[\begin{array}{ll}
a_{11}^{h f} & a_{12}^{h f} \\
a_{21}^{h f} & a_{22}^{h f}
\end{array}\right]\left[\begin{array}{c}
x_{1}^{h h} \\
x_{2}^{h h}
\end{array}\right]\right) \\
& {\left[\begin{array}{l}
v_{1}^{h} b_{11}^{f h}+v_{2}^{h} b_{21}^{f h} \\
v_{2}^{h} b_{12}^{f h}+v_{2}^{h} b_{22}^{f h}
\end{array}\right] \#\left[\begin{array}{c}
y_{1}^{h f} \\
y_{2}^{h f}
\end{array}\right]+\left[\begin{array}{l}
v_{1}^{h} b_{11}^{f h}+v_{2}^{h} b_{21}^{f h} \\
v_{2}^{h} b_{12}^{f h}+v_{2}^{h} b_{22}^{f h}
\end{array}\right] \#\left(\left[\begin{array}{ll}
a_{11}^{h f} & a_{12}^{h f} \\
a_{21}^{h f} & a_{22}^{h f}
\end{array}\right]\left[\begin{array}{ll}
l_{11}^{f f} & l_{12}^{f f} \\
l_{21}^{f f} & l_{22}^{f f}
\end{array}\right]\left[\begin{array}{c}
y_{1}^{f f} \\
y_{2}^{f f}
\end{array}\right]\right)} \\
& +\left[\begin{array}{l}
v_{1}^{h} b_{11}^{f h}+v_{2}^{h} b_{21}^{f h} \\
v_{2}^{h} b_{12}^{f h}+v_{2}^{h} b_{22}^{f h}
\end{array}\right] \#\left(\left[\begin{array}{ll}
a_{11}^{h f} & a_{12}^{h f} \\
a_{21}^{h f} & a_{22}^{h f}
\end{array}\right]\left[\begin{array}{ll}
l_{11}^{f f} & l_{12}^{f f} \\
l_{21}^{f f} & l_{22}^{f f}
\end{array}\right]\left[\begin{array}{l}
e_{1}^{f h} \\
e_{2}^{f h}
\end{array}\right]\right)
\end{aligned}
$$

The first term is domestic value-added embodied in the final exports of the 1 st and 2nd sectors of country $h$ by domestic value-added created by the other sector itself and domestic value-added created by the other sector embodied in the sector's final exports. The second term is domestic value-added embodied in country $h$ 's 1st and 2nd sector's intermediate exports which are used by country $f$ to produce final goods, $y_{1}^{f f}$ and $y_{2}^{f f}$, that are consumed in $f$. The sum of these two terms are the value-added exports of country $h$.

The third term is domestic value-added embodied in country $h$ 's 1 st and 2nd sector's intermediate exports used to produce country $f^{\prime}$ 's final exports, in other way, country $h$ 's imports of final goods from country $f$. The fourth term is the domestic value added embodied in Country h's 1st and 2nd sector's intermediate exports that are used by country $\mathrm{f}$ to produce intermediate exports and return to country $h$ via its intermediate imports to produce its domestic final goods. The first four terms are the domestic value added (GDP) embodied in the 1st and 2nd sectors' gross exports of Country h, which include value added created from all sectors in Country $h$.

The fifth and sixth term is the domestic value added of Country $h$ 's inter- 
mediate exports of 1st and 2nd sector's that returned home and are used for production of country $h$ 's 1st and 2nd sectors' final exports that are finally consumed in country $f$. These are already counted once in the value-added by the first term. These double counted domestic value-added is caused by the backand-forth intermediate goods trade but to produce intermediate goods exports in country $h$.

The seventh term is the foreign value-added imported by country $h$ to produce exportable final goods by both 1st and 2nd sector. Each of the imported intermediate value-added has two parts: foreign value added from the sector itself and from the other sector used to produce final exports in country $h$.

The eighth term is the foreign value-added used to produce the 1st and 2 nd sector intermediate exports of country $h$, which are then used by country $f$ to produce its domestic final goods. The ninth term is the foreign value-added embodied in the 1st and 2nd sector's intermediate exports used by country $f$ to produce its final and intermediate exports, which is a pure foreign double counted term of country $h$ 's exports.

\section{A.3 3-country 2-sectors}

For a two-country, two-sector economy, it is easier to trace down country's exports and imports compared to a multi-country multi-sector settings. To make it clear, now consider a three-country and two-sector settings. We use a superscript $h$, to represent the home country, $f$ to represent the partner country, and $\mathrm{t}$ to represent the third country, and define the country set $G=\{h, f, t\}$. Based on the Leontief insight, from a three-country two-sector ICIO model we can decompose Country f's gross output into the following nine components according to where they are finally absorbed:

$$
\begin{aligned}
& X^{f}=B^{f h} Y^{h}+B^{f f} Y^{f}+B^{f t} Y^{t} \\
= & B^{f h} Y^{h h}+B^{f h} Y^{h f}+B^{f h} Y^{h t}+B^{f f} Y^{f h}+B^{f f} Y^{f f}+B^{f f} Y^{f t}+B^{f t} Y^{t h}+B^{f t} Y^{t f}+B^{f t} Y^{t t}
\end{aligned}
$$

Where $B^{f k}$ denotes a $2 * 2$ Leontief inverse matrix, which is total intermediate input requirement coefficients that specify the amount of gross output from Country $f$ required for a one-unit increase in final demand in country $k . X^{f}$ and $Y^{k}$ are vectors of Country $f^{\prime}$ s gross output and country $k^{\prime}$ s final goods outputs respectively. 


$$
\begin{gathered}
x^{f}=\left[\begin{array}{l}
x_{1}^{f} \\
x_{2}^{f}
\end{array}\right]=\left[\begin{array}{l}
x_{1}^{f h}+x_{1}^{f f}+x_{1}^{f t} \\
x_{2}^{f h}+x_{2}^{f f}+x_{2}^{f t}
\end{array}\right] ; B^{f k}=\left[\begin{array}{ll}
b_{11}^{h k} & b_{12}^{h k} \\
b_{12}^{h k} & b_{22}^{h k}
\end{array}\right] \\
Y^{k}=\left[\begin{array}{l}
y_{1}^{k} \\
y_{2}^{k}
\end{array}\right]=\left[\begin{array}{l}
y_{1}^{k h}+y_{1}^{k h}+y_{1}^{k f}+y_{1}^{k t} \\
y_{2}^{k h}+y_{2}^{k f}+y_{2}^{k f}+y_{2}^{k t}
\end{array}\right] ; k \in G=\{h, f, t\}
\end{gathered}
$$

We can obtain the gross exports decomposition equation in the 3-country, 2-sector model in a similar fashion as the 2-country 2-sector case as follows:

$$
\begin{gathered}
E^{h f}=Y^{h f}+A^{h f} X^{f}=\left(V^{h} B^{h h}\right)^{T} \# Y^{h f}+\left(V^{h} L^{h h}\right)^{T} \#\left(A^{h f} B^{f f} Y^{f f}\right)+\left(V^{h} L^{h h}\right)^{T} \#\left(A^{h f} B^{f t} Y^{t t}\right) \\
+\left(V^{h} L^{h h}\right)^{T} \#\left(A^{h f} B^{f f} Y^{f t}\right)+\left(V^{h} L^{h h}\right)^{T} \#\left(A^{h f} B^{f t} Y^{t f}\right)+\left(V^{h} L^{h h}\right)^{T} \#\left(A^{h f} B^{f f} Y^{f h}\right) \\
+\left(V^{h} L^{h h}\right)^{T} \#\left(A^{h f} B^{f t} Y^{t h}\right)+\left(V^{h} L^{h h}\right)^{T} \#\left(A^{h f} B^{f h} Y^{h h}\right)+\left(V^{h} L^{h h}\right)^{T} \#\left[A^{h f} B^{f f}\left(Y^{h f}+Y^{h t}\right)\right] \\
+\left[V^{h}\left(B^{h h}-L^{h h}\right)\right]^{T} \#\left(A^{h f} X^{f}\right)+\left(V^{f} B^{f h}\right)^{T} \# Y^{h f}+\left(V^{f} B^{f h}\right)^{T} \#\left(A^{h f} L^{f f} Y^{f f}\right)+\left(V^{f} B^{f h}\right)^{T} \# \\
\left(A^{h f} L^{f f} E^{r *}\right)+\left(V^{t} B^{t h}\right)^{T} \# Y^{h f}+\left(V^{f} B^{t h}\right)^{T} \#\left(A^{h f} L^{f f} Y^{f f}\right)+\left(V^{t} B^{t h}\right)^{T} \#\left(A^{h f} L^{f f} E^{r *}\right)
\end{gathered}
$$

Now we are moving towards the general version of the equation as follows:

$$
\begin{aligned}
E^{h f}= & \left(V^{h} B^{h h}\right)^{T} \# Y^{h f}+\left(V^{h} L^{h h}\right)^{T} \#\left(A^{h f} X^{f}\right)+\left(V^{h} B^{h h}-V^{h} L^{h h}\right)^{T} \#\left(A^{h f} X^{f}\right)+\left(V^{h} B^{f h}\right)^{T} \# Y^{h f} \\
& +\left(V^{h} B^{f h}\right)^{T} \#\left(A^{h f} X^{f}\right)+\left(\Sigma_{t \neq s, r}^{G} V^{t} B^{t h}\right)^{T} \# Y^{h f}+\left(\Sigma_{t \neq s, r}^{G} V^{t} B^{t h}\right)^{T} \#\left(A^{h f} X^{f}\right) \\
= & \left(V^{h} B^{h h}\right)^{T} \# Y^{h f}+\left(V^{h} L^{h h}\right)^{T} \#\left(A^{h f} B^{f f} Y^{f f}\right)+\left(V^{h} L^{h h}\right)^{T} \#\left(A^{h f} \Sigma_{t \neq h, f}^{G} B^{f t} Y^{t t}\right) \\
& +\left(V^{f} B^{f h}\right)^{T} \# Y^{h f}+\left(V^{f} B^{f h}\right)^{T} \#\left(A^{h f} L^{f f} Y^{f f}\right)+\left(V^{f} B^{f h}\right)^{T} \#\left(A^{h f} L^{f f} E^{r *}\right) \\
& +\left(V^{t} B^{t h}\right)^{T} \# Y^{h f}+\left(V^{f} B^{t h}\right)^{T} \#\left(A^{h f} L^{f f} Y^{f f}\right)+\left(V^{t} B^{t h}\right)^{T} \#\left(A^{h f} L^{f f} E^{r *}\right)
\end{aligned}
$$

Explanations of each terms of equation (A.9) is similar to equation (A.6). There are few more terms compared to previous equation due to the introduction of third country. Here, four of them are domestic value-added components. The third term is the domestic value-added of country $h$ in its intermediate exports used by the direct importer (country $f$ ) to produce intermediate exports to the third country $t$ for production of latter's domestic final goods. The fourth term is the domestic value-added in country $h$ 's intermediate exports used by the direct importer $(f)$ for producing final goods exports to the third country $t$. The fifth term is the domestic value-added in country $h$ 's intermediate exports used by the direct importer $(f)$ to produce intermediate exports to the 
third country $t$ for its production of final goods exports that are shipped back to the direct importer $(f)$; and the seventh term is the domestic value-added in country $h$ 's intermediate exports used by the direct importer $(f)$ to produce intermediate exports to the third country $t$ for the latter's production of final goods exports that are shipped back to the source country $h$.

The fourteenth term is the foreign value added from the third country $t$ used by country $h$ 's 1st and 2nd sectors to produce final exports from country $h$. The fifteenth term is the foreign value-added from the third country $t$ used to produce the 1st and 2nd sectors' intermediate exports of country $h$, which are then used by country $f$ to produce its domestic final goods.

\section{B Additional Figures and Tables}

Figure 7: WIOD: 3 country Input-Output table structure example

\begin{tabular}{|c|c|c|c|c|c|c|c|c|}
\hline & & $\begin{array}{l}\text { Country A } \\
\text { Industry }\end{array}$ & $\begin{array}{c}\text { Country B } \\
\text { Industry }\end{array}$ & $\begin{array}{c}\text { Country C } \\
\text { Industry }\end{array}$ & Country A & Country B & Country C & Total \\
\hline Country A & 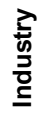 & $\begin{array}{c}\text { Intermediate use } \\
\text { by A of domestic } \\
\text { output }\end{array}$ & $\begin{array}{c}\text { Intermediate } \\
\text { use by B of } \\
\text { exports from } A\end{array}$ & $\begin{array}{c}\text { Intermediate } \\
\text { use by } C \text { of } \\
\text { exports from } A\end{array}$ & $\begin{array}{c}\text { Final use by } A \\
\text { of domestic } \\
\text { output }\end{array}$ & $\begin{array}{c}\text { Final use by } B \\
\text { of exports } \\
\text { from } A\end{array}$ & $\begin{array}{c}\text { Final use by } C \\
\text { of exports } \\
\text { from } A\end{array}$ & $\begin{array}{c}\text { Output } \\
\text { in } A\end{array}$ \\
\hline Country B & 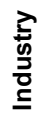 & $\begin{array}{l}\text { Intermediate use } \\
\text { by A of exports } \\
\text { from B }\end{array}$ & $\begin{array}{c}\text { Intermediate use } \\
\text { by B of domestic } \\
\text { output }\end{array}$ & $\begin{array}{c}\text { Intermediate use } \\
\text { by } C \text { of exports } \\
\text { from B }\end{array}$ & $\begin{array}{c}\text { Final use by } A \\
\text { of exports } \\
\text { from } B\end{array}$ & $\begin{array}{c}\text { Final use by B } \\
\text { of domestic } \\
\text { output }\end{array}$ & $\begin{array}{c}\text { Final use by C } \\
\text { of exports from } \\
\text { B }\end{array}$ & $\begin{array}{l}\text { Output } \\
\text { in B }\end{array}$ \\
\hline \multirow[t]{3}{*}{ Country C } & \multirow[t]{3}{*}{ 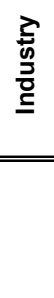 } & $\begin{array}{l}\text { Intermediate use } \\
\text { by A of exports } \\
\text { from C }\end{array}$ & $\begin{array}{c}\text { Intermediate use } \\
\text { by B of exports } \\
\text { from C }\end{array}$ & $\begin{array}{c}\text { Intermediate use } \\
\text { by } \mathrm{C} \text { of domestic } \\
\text { output }\end{array}$ & $\begin{array}{c}\text { Final use by } A \\
\text { of exports } \\
\text { from C }\end{array}$ & $\begin{array}{c}\text { Final use by B } \\
\text { of exports from } \\
\text { C }\end{array}$ & $\begin{array}{c}\text { Final use by C } \\
\text { of domestic } \\
\text { output }\end{array}$ & $\begin{array}{l}\text { Output } \\
\text { in } C\end{array}$ \\
\hline & & $\begin{array}{c}\begin{array}{c}\text { Value added by } \\
\text { labour and } \\
\text { capital in } A\end{array} \\
\end{array}$ & $\begin{array}{c}\text { Value added by } \\
\text { labour and } \\
\text { capital in B }\end{array}$ & \begin{tabular}{|c|} 
Value added by \\
labour and capital \\
in C
\end{tabular} & & & & \\
\hline & & Output in A & Output in B & Output in C & & & & \\
\hline
\end{tabular}

source: Timmer et al. (2014a) 
Table 4: Estimated Exchange Rate Pass-Through $(\lambda)$ and Elasticity of Substitution $(\sigma)$

\begin{tabular}{|c|c|c|c|c|}
\hline \multirow[t]{2}{*}{ Sectors } & \multicolumn{2}{|c|}{ Estimates based on value added export } & \multicolumn{2}{|c|}{ Estimates based on $100 \%$ domestic contents } \\
\hline & $\sigma$ & $\lambda$ & $\sigma$ & $\lambda$ \\
\hline Agri_Forest_Fishing & 0.770 & 1.022 & 0.815 & 0.908 \\
\hline Mining_Quarrying & 1.007 & -33.529 & 0.969 & 5.111 \\
\hline Food, Beverages and Tobacco & 0.937 & 3.470 & 0.969 & 4.595 \\
\hline Textiles and Textile Products & 0.845 & 1.316 & 0.862 & 1.065 \\
\hline Leather, Leather P and Footwear & 0.821 & 0.844 & 0.836 & 0.756 \\
\hline Wood_Products_Cork & 0.794 & 0.587 & 0.794 & 0.483 \\
\hline Paper_Printing_Publishing & 0.870 & 2.169 & 0.896 & 2.038 \\
\hline Petroleum_Nuclear_Fuel & 0.548 & 0.825 & 0.609 & 0.688 \\
\hline Chemicals_Chemical_Products & 0.913 & -0.270 & 0.870 & 0.064 \\
\hline Rubber and Plastics & 0.742 & 1.043 & 0.743 & 0.732 \\
\hline Other Non-Metallic Mineral & 0.808 & 0.316 & 0.583 & 0.135 \\
\hline Basic_Fabricated_Metal & 0.693 & 0.629 & 0.639 & 0.593 \\
\hline Machinery, Nec & 0.978 & 0.548 & 0.967 & 0.480 \\
\hline Electrical_Optical_Equipment & 1.268 & -0.234 & 1.215 & -0.167 \\
\hline Transport Equipment & 0.664 & 0.750 & 0.694 & 0.598 \\
\hline Manufacturing & 1.027 & 4.850 & 0.996 & -34.163 \\
\hline Electricity_Gas_Water & 2.282 & 0.287 & 1.950 & 0.341 \\
\hline Construction & 0.886 & 0.991 & 0.887 & 0.785 \\
\hline Monotor Vehicle_Services & 0.951 & 0.674 & 0.975 & 0.130 \\
\hline Wholesale_Trade_NonMotor & 0.908 & 1.528 & 0.838 & 0.590 \\
\hline Retail_Trade_NonMotor & 0.889 & 2.306 & 0.854 & 1.356 \\
\hline Hotels_Restaurants & 1.264 & 0.879 & 1.059 & 0.793 \\
\hline Inland_Transport & 0.674 & 0.883 & 0.705 & 0.793 \\
\hline Water_Transport & 1.113 & -0.232 & 1.031 & -0.481 \\
\hline Air_Transport & 0.915 & 2.192 & 0.949 & 2.237 \\
\hline Other_Transport & 0.878 & 1.500 & 0.691 & 0.469 \\
\hline Post_Telecommunications & 2.070 & -0.377 & 1.793 & -0.433 \\
\hline Financial_Intermediation & 0.749 & 1.291 & 0.751 & 1.104 \\
\hline Real_Estate_Activities & -6.932 & 0.075 & -7.251 & 0.061 \\
\hline Renting_Other_Business & 0.858 & 1.437 & 0.943 & 1.545 \\
\hline Public_Admin_Defence & 0.754 & 0.972 & 0.771 & 0.790 \\
\hline Education & 0.788 & 1.759 & 0.830 & 1.541 \\
\hline Health_Social Work & 0.899 & 2.436 & 0.914 & 2.282 \\
\hline Other_Social_Personal_Services & 0.621 & 0.852 & 0.640 & 0.778 \\
\hline Private_HH_Employed_Persons & 0.693 & 0.378 & 0.685 & 0.365 \\
\hline
\end{tabular}


Table 5: ERPT and elasticity of substitution by sectors

\begin{tabular}{|c|c|c|c|c|c|c|c|c|c|c|c|c|}
\hline \multirow[b]{2}{*}{ VARIABLES } & \multicolumn{2}{|c|}{$\mathrm{rdv}$} & \multicolumn{2}{|c|}{ rdv_int } & \multicolumn{2}{|c|}{ rdv_fin } & \multicolumn{2}{|c|}{ dva_int } & \multicolumn{2}{|c|}{ texp } & \multicolumn{2}{|c|}{ texp_int } \\
\hline & $\sigma$ & $\lambda$ & $\mathrm{s} \sigma$ & $\lambda$ & $\sigma$ & $\lambda$ & $\sigma$ & $\lambda$ & $\sigma$ & $\lambda$ & $\sigma$ & $\lambda$ \\
\hline Agri_Forest_Fishing & 1.226 & 0.023 & 1.081 & -0.021 & 0.730 & 0.003 & 1.102 & -0.054 & 1.079 & -0.069 & 1.094 & -0.062 \\
\hline Mining_Quarrying & 1.064 & 0.025 & 1.204 & 0.070 & 0.982 & 0.250 & 1.249 & 0.167 & 1.018 & 2.591 & 1.268 & 0.173 \\
\hline Food, Beverages and Tobacco & 0.990 & & 1.063 & 0.852 & 0.973 & $-0.088:$ & 0.985 & -1.532 & 0.905 & -0.252 & 0.967 & -0.833 \\
\hline Textiles and Textile Products & 1.284 & 0.005 & 1.278 & 0.005 & 1.142 & $0.000:$ & 1.353 & 0.006 & 1.314 & 0.008 & 1.351 & 0.007 \\
\hline Leather, Leather and Footwear & 1.501 & -0.194 & 1.208 & -0.047 & 1.462 & $0.431:$ & 1.290 & -0.042 & 1.536 & 0.374 & 1.327 & -0.040 \\
\hline Wood_Products_Cork & 1.511 & 0.002 & 1.456 & 0.002 & 2.047 & $\begin{array}{l:l}-0.001 & \vdots\end{array}$ & 1.786 & 0.001 & 2.011 & -0.001 & 1.865 & 0.000 \\
\hline Paper_Printing_Publishing & 1.528 & 0.064 & 1.171 & -0.090 & 1.366 & $-0.022 \vdots$ & 1.225 & -0.334 & 1.621 & -0.021 & 1.212 & -0.362 \\
\hline Petroleum_Nuclear_Fuel & 1.769 & -0.020 & 1.267 & -0.024 & 1.517 & -0.045 & 1.389 & -0.048 & 1.473 & -0.058 & 1.408 & -0.048 \\
\hline Chemicals_Chemical_Products & 1.190 & -0.326 & 1.055 & 0.002 & 1.099 & 0.002 & 1.092 & 0.000 & 0.945 & -0.002 & 1.097 & 0.000 \\
\hline Rubber and Plastics & 1.251 & 0.755 & 1.099 & 1.878 & 1.089 & & 1.131 & 2.770 & 1.077 & & 1.137 & 2.702 \\
\hline Other Non-Metallic Mineral & 1.559 & 1.008 & 1.004 & & 1.049 & & 1.014 & 2.292 & 1.044 & & 1.013 & 2.373 \\
\hline Basic_Fabricated_Metal & 1.351 & -0.001 & 1.142 & 0.000 & 0.976 & 0.000 & 1.067 & 0.007 & 1.050 & 0.010 & 1.050 & 0.010 \\
\hline Machinery, Nec & 1.347 & 0.314 & 1.081 & 0.004 & 1.080 & -0.043 & 1.047 & 0.078 & 1.057 & 0.063 & 1.053 & 0.068 \\
\hline Electrical_Optical_Equipment & 0.839 & 0.004 & 0.944 & 0.009 & 0.878 & 0.336 & 0.895 & 0.006 & 0.866 & 0.022 & 0.899 & 0.006 \\
\hline Transport Equipr & 1.625 & 0.038 & 1.092 & -0.866 & 1.247 & -0.013 & 1.144 & -0.974 & 1.220 & -0.057 & 1.154 & -0.981 \\
\hline Manu & 2.108 & 0.018 & 1.191 & -0.024 & 1.262 & 0.205 & 1.208 & -0.050 & 1.384 & 0.110 & 1.227 & -0.051 \\
\hline Electricity_Gas_Water & 2.008 & 0.024 & 1.173 & 0.002 & 1.162 & -0.006 & 1.219 & -0.005 & 1.150 & -0.008 & 1.219 & -0.005 \\
\hline Construction & 1.400 & -0.003 & 1.151 & -0.005 & 1.098 & -0.070 & 1.199 & -0.008 & 1.275 & -0.027 & 1.212 & -0.008 \\
\hline Monotor Vehicle_Services & 1.600 & 0.109 & 1.220 & 0.152 & 1.229 & -0.681 & 1.286 & -0.031 & 1.223 & 0.002 & 1.296 & 0.005 \\
\hline Wholesale_Trade_NonMotor & 1.301 & -0.017 & 1.190 & 0.022 & 1.508 & -0.101 & 1.271 & 0.028 & 1.309 & 0.013 & 1.272 & 0.027 \\
\hline Retail_Trade_NonMotor & 1.142 & 0.042 & 1.172 & 0.017 & 1.546 & -0.001 & 1.349 & 0.036 & 1.518 & 0.025 & 1.362 & 0.035 \\
\hline Hotels_Restaurants & 1.148 & 0.077 & 0.998 & & 1.036 & & 0.992 & & 1.006 & & 0.983 & \\
\hline Inland_Transport & 1.289 & -0.027 & 1.360 & -0.009 & 1.043 & 0.313 & 1.746 & -0.011 & 1.190 & 0.034 & 1.759 & -0.012 \\
\hline Water_Transport & 1.283 & 0.088 & 1.178 & 0.019 & 1.101 & 0.085 & 1.202 & 0.048 & 1.202 & 0.096 & 1.213 & 0.048 \\
\hline Air_Transport & 1.218 & -0.026 & 0.927 & 0.306 & 1.089 & -0.104 & 0.876 & 0.428 & 1.065 & -0.146 & 0.870 & 0.408 \\
\hline Other_Transport & 0.814 & -0.828 & 1.026 & 0.360 & 1.000 & & 1.046 & 0.699 & 1.003 & & 1.046 & 0.580 \\
\hline Post_Telecommun & 3.497 & -0.159 & 0.988 & & 0.944 & & $\begin{array}{l}0.969 \\
\end{array}$ & 2.130 & 0.956 & & 0.969 & 1.388 \\
\hline Financial_Intermediation & 1.214 & 0.034 & 1.067 & 0.134 & 1.272 & 0.013 & 1.063 & 0.174 & 1.142 & 0.054 & 1.061 & 0.178 \\
\hline Real_Estate_Activities & 1 & 0.019 & 0.995 & & 0.988 & & 0.993 & & 0.984 & & 0.993 & \\
\hline Renting_Other_Business & 1.339 & -0.058 & 1.165 & -0.006 & 0.971 & 0.150 & 1.171 & -0.010 & 1.031 & -0.228 & 1.198 & -0.011 \\
\hline Public_Admin_Defence & 1.410 & -0.048 & 1.097 & -0.079 & 1.085 & 0.369 & 1.174 & -0.015 & 1.161 & 0.195 & 1.209 & -0.265 \\
\hline Education & 1.314 & -0.117 & 1.141 & -0.045 & 0.639 & -0.029 & 1.063 & -0.134 & 0.655 & 0.017 & 1.069 & -0.103 \\
\hline Health_Social Work & 1.187 & 0.068 & 1.103 & -0.001 & 1.169 & -0.012 & 1.040 & 0.003 & 1.269 & -0.003 & 1.027 & 0.004 \\
\hline Other_Social_Personal_Services & 1.321 & -0.010 & 1.216 & 0.006 & 1.200 & 0.019 & 1.271 & 0.005 & 1.406 & 0.016 & 1.262 & 0.007 \\
\hline Private_HH_Employed_Persons & 1.390 & -0.005 & 1.157 & 0.016 & 1.582 & -0.001 & 0.947 & -0.187 & 0.925 & -0.152 & 0.896 & -0.110 \\
\hline
\end{tabular}


Table 6: Estimated Exchange Rate Pass-Through $(\lambda)$ and Elasticity of Substitution $(\sigma)$ for Manufacturing Sectors

\begin{tabular}{|c|c|c|c|}
\hline Sectors & $\lambda$ & $\sigma$ & F-Statistic \\
\hline Food, Beverages, and Tobacco & $\begin{array}{c}2.840 \\
(9.632)\end{array}$ & $\begin{array}{ll}1.061 \\
(0.436)\end{array}$ & $\begin{array}{cc}5.020 \\
(0.013)\end{array}$ \\
\hline Textile and Textile Product & $\begin{array}{c}0.293 \\
(0.323)\end{array}$ & $\begin{array}{c}1.763 \\
(0.300)\end{array}$ & $\begin{array}{c}5.100 \\
(0.005)\end{array}$ \\
\hline Leather Products & $\begin{array}{c}0.576 \\
(0.130)\end{array}$ & $\begin{array}{c}1.673 \\
(0.345)\end{array}$ & $\begin{array}{c}5.200 \\
(0.007)\end{array}$ \\
\hline Wood Products & $\begin{array}{c}0.504 \\
(0.032)\end{array}$ & $\begin{array}{c}2.272 \\
(0.243)\end{array}$ & $\begin{array}{l}19.780 \\
(0.000)\end{array}$ \\
\hline Paper & $\begin{array}{c}0.815 \\
(0.344)\end{array}$ & $\begin{array}{cc}1.238 \\
(0.323)\end{array}$ & $\begin{array}{c}1.500 \\
(0.221)\end{array}$ \\
\hline Chemicals & $\begin{array}{c}0.384 \\
(0.131)\end{array}$ & $\begin{array}{cc}1.908 \\
(0.212)\end{array}$ & $\begin{array}{l}15.210 \\
(0.000)\end{array}$ \\
\hline Rubber and Plastic Products & $\begin{array}{cc}1.199 \\
(0.021)\end{array}$ & $\begin{array}{c}1.403 \\
(0.214)\end{array}$ & $\begin{array}{l}30.050 \\
(0.000)\end{array}$ \\
\hline Non-Metallic Mineral Products & $\begin{array}{c}0.435 \\
(0.043)\end{array}$ & $\begin{array}{c}2.343 \\
(0.321)\end{array}$ & $\begin{array}{l}12.800 \\
(0.000)\end{array}$ \\
\hline Metal Products & $\begin{array}{c}0.511 \\
(0.502)\end{array}$ & $\begin{array}{c}1.533 \\
(0.401)\end{array}$ & $\begin{array}{c}3.090 \\
(0.072)\end{array}$ \\
\hline Machinery & $\begin{array}{c}0.090 \\
(0.034)\end{array}$ & $\begin{array}{c}1.811 \\
(0.200)\end{array}$ & $\begin{array}{c}7.530 \\
(0.000)\end{array}$ \\
\hline Electrical and Optical Equipment & $\begin{array}{c}0.234 \\
(0.032)\end{array}$ & $\begin{array}{c}1.911 \\
(0.120)\end{array}$ & $\begin{array}{l}17.010 \\
(0.000)\end{array}$ \\
\hline Transportation Equipment & $\begin{array}{c}-0.043 \\
(0.141)\end{array}$ & $\begin{array}{c}1.884 \\
(0.320)\end{array}$ & $\begin{array}{c}5.670 \\
(0.009)\end{array}$ \\
\hline Other Manufacturing & $\begin{array}{c}1.132 \\
(0.456)\end{array}$ & $\begin{array}{c}1.291 \\
(0.213)\end{array}$ & $\begin{array}{l}23.430 \\
(0.000)\end{array}$ \\
\hline Median & $0 . \overline{5} 04^{-}$ & 1.763 & $7 . \overline{530}$ \\
\hline
\end{tabular}


Table 7: Regression Coefficients using Value-added shares for Manufacturing sectors

\begin{tabular}{|c|c|c|c|c|}
\hline Sectors & $\beta_{0}$ & $\beta_{1}$ & $\beta_{2}$ & $R^{2}$ \\
\hline \multirow[t]{2}{*}{ Food, Beverages, and Tobacco } & 0.0519 & 0.0614 & -0.1744 & 0.0065 \\
\hline & $(0.0109)$ & $(0.0875)$ & $(0.0508)$ & \\
\hline \multirow[t]{2}{*}{ Textiles and Textile Products } & 0.0615 & 0.7630 & -0.2236 & 0.0524 \\
\hline & $(0.0093)$ & $(0.1399)$ & $(0.0729)$ & \\
\hline \multirow[t]{2}{*}{ Leather, Leather P and Footwear } & 0.0912 & 0.6734 & -0.3880 & 0.0029 \\
\hline & $(0.0110)$ & $(0.2538)$ & $(0.0953)$ & \\
\hline \multirow[t]{2}{*}{ Wood_Products_Cork } & -0.0183 & 1.2717 & -0.6412 & 0.0099 \\
\hline & $(0.0101)$ & $(0.2343)$ & $(0.0922)$ & \\
\hline \multirow[t]{2}{*}{ Paper_Printing_Publishing } & 0.0347 & 0.2383 & -0.1941 & 0.0016 \\
\hline & $(0.0081)$ & $(0.2369)$ & $(0.0490)$ & \\
\hline \multirow[t]{2}{*}{ Chemicals } & 0.0638 & 0.9076 & -0.3488 & 0.0126 \\
\hline & $(0.0090)$ & $(0.2477)$ & $(0.0716)$ & \\
\hline \multirow[t]{2}{*}{ Rubber and Plastic Products } & 0.0413 & 0.4029 & -0.4831 & 0.0195 \\
\hline & $(0.0076)$ & $(0.1804)$ & $(0.0702)$ & \\
\hline \multirow[t]{2}{*}{ Non-Metallic Mineral Products } & -0.0238 & 1.3428 & -0.5846 & 0.0110 \\
\hline & $(0.0096)$ & $(0.2132)$ & $(0.0931)$ & \\
\hline \multirow[t]{2}{*}{ Metal Products } & 0.0607 & 0.5329 & -0.2721 & 0.0018 \\
\hline & $(0.0119)$ & $(0.4339)$ & $(0.0941)$ & \\
\hline \multirow[t]{2}{*}{ Machinery } & 0.0514 & 0.8105 & -0.0730 & 0.0236 \\
\hline & $(0.0074)$ & $(0.0893)$ & $(0.0174)$ & \\
\hline \multirow[t]{2}{*}{ Electrical and Optical Equipment } & 0.0326 & 0.9107 & -0.2134 & 0.0092 \\
\hline & $(0.0074)$ & $(0.0721)$ & $(0.0271)$ & \\
\hline \multirow[t]{2}{*}{ Transportation Equipment } & 0.0428 & 0.8843 & 0.0378 & 0.0232 \\
\hline & $(0.0114)$ & $(0.2639)$ & $(0.0627)$ & \\
\hline \multirow[t]{2}{*}{ Other Manufacturing } & 0.0572 & 0.2913 & -0.3298 & 0.0084 \\
\hline & $(0.0034)$ & $(0.2353)$ & $(0.0823)$ & \\
\hline
\end{tabular}


Table 8: Regression Coefficients for foreign (intermediate) value-added shares in exported items.

\begin{tabular}{|c|c|c|c|c|c|c|c|c|}
\hline \multirow[t]{2}{*}{ VARIABLES } & \multicolumn{2}{|c|}{ First-Diff. of $\ln ($ PriceIndex) } & \multicolumn{2}{|c|}{ diff of log of exrate } & \multicolumn{2}{|c|}{ Constant } & \multirow[t]{2}{*}{ Observations } & \multirow[t]{2}{*}{ R-squared } \\
\hline & $\beta_{1}$ & (Std Err) & $\beta_{2}$ & (Std Err) & $\beta_{0}$ & (Std Err) & & \\
\hline Agri_Forest_Fishing & $-0.230^{* * *}$ & $(0.0501)$ & $0.235^{* * *}$ & $(0.0356)$ & $0.0721^{* * *}$ & $(0.00508)$ & 15,229 & 0.003 \\
\hline Mining_Quarrying & 0.00680 & $(0.0606)$ & $0.228^{* * *}$ & $(0.0277)$ & $0.103^{* * *}$ & $(0.00387)$ & 15,180 & 0.006 \\
\hline Food, Beverages and Tobacco & -0.0634 & $(0.0474)$ & $0.220^{* * *}$ & $(0.0273)$ & $0.0596^{* * *}$ & $(0.00407)$ & 14,967 & 0.005 \\
\hline Textiles and Textile Products & $-0.155^{* * *}$ & $(0.0475)$ & $0.204^{* * *}$ & $(0.0303)$ & $0.0987^{* * *}$ & $(0.00467)$ & 18,430 & 0.003 \\
\hline Leather, Leather and Footwear & $-0.179^{* * *}$ & $(0.0466)$ & $0.151^{* * *}$ & $(0.0271)$ & $0.104^{* * *}$ & $(0.00428)$ & 18,918 & 0.002 \\
\hline Wood_Products_Cork & $-0.206^{* * *}$ & $(0.0607)$ & $0.121^{* * *}$ & $(0.0278)$ & $0.107^{* * *}$ & $(0.00459)$ & 19,014 & 0.001 \\
\hline Paper_Printing_Publishing & -0.130 & $(0.0895)$ & $0.282^{* * *}$ & $(0.0417)$ & $0.113^{* * *}$ & $(0.00678)$ & 16,775 & 0.003 \\
\hline Petroleum_Nuclear_Fuel & $-0.452^{* * *}$ & $(0.0554)$ & $0.373^{* * *}$ & $(0.0312)$ & $0.106^{* * *}$ & $(0.00438)$ & 16,068 & 0.010 \\
\hline Chemicals_Chemical_Products & -0.0866 & (0.110) & -0.0234 & $(0.0880)$ & $0.125^{* * *}$ & $(0.00895)$ & 7,712 & 0.000 \\
\hline Rubber and Plastics & $-0.258^{* *}$ & (0.128) & $0.269^{* * *}$ & $(0.0817)$ & $0.0953^{* * *}$ & $(0.0108)$ & 6,779 & 0.002 \\
\hline Other Non-Metallic Mineral & -0.192 & (0.339) & 0.0606 & $(0.113)$ & $0.0632^{* * *}$ & $(0.0175)$ & 3,382 & 0.000 \\
\hline Basic_Fabricated_Metal & $-0.307^{* * *}$ & (0.115) & $0.193^{* * *}$ & $(0.0727)$ & $0.0953^{* * *}$ & $(0.0105)$ & 9,258 & 0.001 \\
\hline Machinery, Nec & -0.0217 & $(0.0962)$ & 0.0119 & $(0.0578)$ & $0.0785^{* * *}$ & $(0.00760)$ & 10,577 & 0.000 \\
\hline Electrical_Optical_Equipment & $0.268^{* *}$ & (0.133) & 0.0627 & $(0.0730)$ & $0.0397^{* * *}$ & $(0.00913)$ & 7,189 & 0.001 \\
\hline Transport Equipment & $-0.336^{*}$ & (0.184) & $0.252^{* * *}$ & $(0.0870)$ & $0.102^{* * *}$ & $(0.0110)$ & 5,699 & 0.002 \\
\hline Manufacturing & 0.0266 & $(0.191)$ & $-0.129^{* *}$ & $(0.0649)$ & $0.0840^{* * *}$ & $(0.0112)$ & 10,513 & 0.000 \\
\hline Electricity_Gas_Water & $1.282^{* * *}$ & $(0.397)$ & $-0.368^{* * *}$ & $(0.0941)$ & 0.00656 & $(0.0163)$ & 6,976 & 0.003 \\
\hline Construction & -0.114 & $(0.0781)$ & $0.113^{* *}$ & $(0.0442)$ & $0.101^{* * *}$ & $(0.00622)$ & 11,846 & 0.001 \\
\hline Monotor Vehicle_Services & -0.0487 & $(0.137)$ & 0.0328 & $(0.0537)$ & $0.0974^{* * *}$ & $(0.00771)$ & 11,546 & 0.000 \\
\hline Wholesale_Trade_NonMotor & -0.0916 & $(0.123)$ & $0.140^{* *}$ & $(0.0672)$ & $0.107^{* * *}$ & $(0.00866)$ & 10,186 & 0.000 \\
\hline Retail_Trade_NonMotor & -0.111 & $(0.162) !$ & $0.256^{* * *}$ & $(0.0804)$ & $0.0628^{* * *}$ & $(0.0111)$ & 10,139 & 0.001 \\
\hline Hotels_Restaurants & 0.264 & $(0.335)$ & -0.232 & $(0.225)$ & $0.0882^{* * *}$ & $(0.0257)$ & 2,144 & 0.001 \\
\hline Inland_Transport & $-0.326^{* * *}$ & $(0.0366)$ & $0.288^{* * *}$ & $(0.0234)$ & $0.0925^{* * *}$ & $(0.00360)$ & 18,514 & 0.009 \\
\hline Water_Transport & 0.113 & $(0.107)$ & 0.0262 & $(0.0515)$ & $0.121^{* * *}$ & $(0.00675)$ & 14,341 & 0.000 \\
\hline Air_Transport & -0.0853 & $(0.177)$ & $0.187^{* *}$ & $(0.0939)$ & $0.0592^{* * *}$ & $(0.0115)$ & 5,854 & 0.001 \\
\hline Other_Transport & -0.122 & $(0.817)$ & 0.183 & $(0.146)$ & $0.0605^{* *}$ & $(0.0260)$ & 2,691 & 0.001 \\
\hline Post_Telecommunications & 1.070 & $(0.848)$ & $0.403^{* *}$ & $(0.157)$ & 0.0386 & $(0.0254)$ & 2,708 & 0.004 \\
\hline Financial_Intermediation & $-0.251^{*}$ & $(0.145)$ & $0.324^{* * *}$ & $(0.0779)$ & $0.0899^{* * *}$ & $(0.00870)$ & 9,055 & 0.002 \\
\hline Real_Estate_Activities & $-7.932^{* *}$ & (3.080) & 0.596 & $(0.701)$ & $0.280^{* *}$ & $(0.109)$ & 105 & 0.078 \\
\hline Renting_Other_Business & $-0.142^{* * *}$ & $(0.0365)$ & $0.204^{* * *}$ & $(0.0233)$ & $0.0416^{* * *}$ & $(0.00332)$ & 18,215 & 0.005 \\
\hline Public_Admin_Defence & $-0.246^{* * *}$ & $(0.0553)$ & $0.239^{* * *}$ & $(0.0338)$ & $0.0459^{* * *}$ & $(0.00451)$ & 12,134 & 0.005 \\
\hline Education & $-0.212^{* * *}$ & $(0.0647)$ & $0.373^{* * *}$ & $(0.0384)$ & $0.0731^{* * *}$ & $(0.00486)$ & 12,160 & 0.009 \\
\hline Health_Social Work & $-0.101^{*}$ & $(0.0609)$ & $0.246^{* * *}$ & $(0.0278)$ & $0.0688^{* * *}$ & $(0.00451)$ & 15,005 & 0.006 \\
\hline Other_Social_Personal_Services & $-0.379^{* * *}$ & $(0.102)$ & $0.323^{* * *}$ & $(0.0701)$ & $0.159^{* * *}$ & $(0.00972)$ & 11,131 & 0.002 \\
\hline Private_HH_Employed_Persons & $-0.307^{* * *}$ & $(0.0379)$ & $0.116^{* * *}$ & $(0.0234)$ & $0.110^{* * *}$ & $(0.00373)$ & 18,801 & 0.004 \\
\hline
\end{tabular}

Note: Robust standard errors in parentheses, ${ }^{* * *} \mathrm{p}<0.01,{ }^{* *} \mathrm{p}<0.05,{ }^{*} \mathrm{p}<0.1$ 
Table 9: Regression Coefficients for $100 \%$ domestic value-added shares in exported items.

\begin{tabular}{|c|c|c|c|c|c|c|c|c|}
\hline \multirow[t]{2}{*}{ VARIABLES } & \multicolumn{2}{|c|}{ First-Diff $\ln ($ PriceIndex $)$} & \multicolumn{2}{|c|}{ diff of log of exrate } & \multicolumn{2}{|c|}{ Constant } & \multirow[t]{2}{*}{ Observations } & \multirow[t]{2}{*}{$R^{2}$} \\
\hline & $\beta_{1}$ & (Std err) & $\beta_{2}$ & (Std err) & $\beta_{0}$ & (Std err) & & \\
\hline Agri_Forest_Fishing & $-0.230^{* * *}$ & $(0.0501)$ & $0.235^{* * *}$ & $(0.0356)$ & $0.0721^{* * *}$ & $(0.00508)$ & 15,229 & 0.003 \\
\hline Mining_Quarrying & 0.00680 & $(0.0606)$ & $0.228^{* * *}$ & $(0.0277)$ & $0.103^{* * *}$ & $(0.00387)$ & 15,180 & 0.006 \\
\hline Food, Beverages and Tobacco & -0.0634 & $(0.0474)$ & $0.220^{* * *}$ & $(0.0273)$ & $0.0596^{* * * *}$ & $(0.00407)$ & 14,967 & 0.005 \\
\hline Textiles and Textile Products & $-0.155^{* * *}$ & $(0.0475)$ & $0.204^{* * *}$ & $(0.0303)$ & $0.0987^{* * *}$ & $(0.00467)$ & 18,430 & 0.003 \\
\hline Leather, Leather and Footwear & $-0.179^{* * *}$ & $(0.0466)$ & $0.151^{* * *}$ & $(0.0271)$ & $0.104^{* * *}$ & $(0.00428)$ & 18,918 & 0.002 \\
\hline Wood_Products_Cork & $-0.206^{* * *}$ & $(0.0607)$ & $0.121^{* * *}$ & $(0.0278)$ & $0.107^{* * *}$ & $(0.00459)$ & 19,014 & 0.001 \\
\hline Paper_Printing_Publishing & -0.130 & $(0.0895)$ & $0.282^{* * *}$ & $(0.0417)$ & $0.113^{* * *}$ & $(0.00678)$ & 16,775 & 0.003 \\
\hline Petroleum_Nuclear_Fuel & $-0.452^{* * *}$ & $(0.0554)$ & $0.373^{* * *}$ & $(0.0312)$ & $0.106^{* * *}$ & $(0.00438)$ & 16,068 & 0.010 \\
\hline Chemicals_Chemical_Products & -0.0866 & $(0.110)$ & -0.0234 & $(0.0880)$ & $0.125^{* * *}$ & $(0.00895)$ & 7,712 & 0.000 \\
\hline Rubber and Plastics & $-0.258^{* *}$ & $(0.128)$ & $0.269^{* * *}$ & $(0.0817)$ & $0.0953^{* * *}$ & $(0.0108)$ & 6,779 & 0.002 \\
\hline Other Non-Metallic Mineral & -0.192 & $(0.339)$ & 0.0606 & $(0.113)$ & $0.0632^{* * *}$ & $(0.0175)$ & 3,382 & 0.000 \\
\hline Basic_Fabricated_Metal & $-0.307^{* * *}$ & (0.115) & $0.193^{* * *}$ & $(0.0727)$ & $0.0953^{* * *}$ & $(0.0105)$ & 9,258 & 0.001 \\
\hline Machinery, Nec & -0.0217 & $(0.0962)$ & 0.0119 & $(0.0578)$ & $0.0785^{* * *}$ & $(0.00760)$ & 10,577 & 0.000 \\
\hline Electrical_Optical_Equipment & $0.268^{* *}$ & $(0.133)$ & 0.0627 & $(0.0730)$ & $0.0397^{* * *}$ & $(0.00913)$ & 7,189 & 0.001 \\
\hline Transport Equipment & $-0.336^{*}$ & $(0.184)$ & $0.252^{* * *}$ & $(0.0870)$ & $0.102^{* * *}$ & $(0.0110)$ & 5,699 & 0.002 \\
\hline Manufacturing & 0.0266 & $(0.191)$ & $-0.129^{* *}$ & $(0.0649):$ & $0.0840^{* * *}$ & $(0.0112)$ & 10,513 & 0.000 \\
\hline Electricity_Gas_Water & $1.282^{* * *}$ & $(0.397)$ & $-0.368^{* * *}$ & $(0.0941)$ & 0.00656 & $(0.0163)$ & 6,976 & 0.003 \\
\hline Construction & -0.114 & $(0.0781)$ & $0.113^{* *}$ & $(0.0442)$ & $0.101^{* * *}$ & $(0.00622)$ & 11,846 & 0.001 \\
\hline Monotor Vehicle_Services & -0.0487 & $(0.137)$ & 0.0328 & $(0.0537)$ & $0.0974^{* * *}$ & $(0.00771)$ & 11,546 & 0.000 \\
\hline Wholesale_Trade_NonMotor & -0.0916 & $(0.123)$ & $0.140^{* *}$ & $(0.0672)$ & $0.107^{* * *}$ & $(0.00866)$ & 10,186 & 0.000 \\
\hline Retail_Trade_NonMotor & -0.111 & $(0.162)$ & $0.256^{* * *}$ & (0.0804) & $0.0628^{* * *}$ & $(0.0111)$ & 10,139 & 0.001 \\
\hline Hotels_Restaurants & 0.264 & $(0.335)$ & -0.232 & $(0.225)$ & $0.0882^{* * *}$ & $(0.0257)$ & 2,144 & 0.001 \\
\hline Inland_Transport & $-0.326^{* * *}$ & $(0.0366)$ & $0.288^{* * *}$ & $(0.0234)$ & $0.0925^{* * *}$ & $(0.00360)$ & 18,514 & 0.009 \\
\hline Water_Transport & 0.113 & $(0.107)$ & 0.0262 & $(0.0515)$ & $0.121^{* * *}$ & $(0.00675)$ & 14,341 & 0.000 \\
\hline Air_Transport & -0.0853 & $(0.177)$ & $0.187^{* *}$ & $(0.0939)$ & $0.0592^{* * *}$ & $(0.0115)$ & 5,854 & 0.001 \\
\hline Other_Transport & -0.122 & $(0.817)$ & 0.183 & $(0.146)$ & $0.0605^{* *}$ & $(0.0260)$ & 2,691 & 0.001 \\
\hline Post_Telecommunications & 1.070 & $(0.848)$ & $0.403^{* *}$ & $(0.157)$ & 0.0386 & $(0.0254)$ & 2,708 & 0.004 \\
\hline Financial_Intermediation & $-0.251^{*}$ & $(0.145)$ & $0.324^{* * *}$ & $(0.0779)$ & $0.0899^{* * *}$ & $(0.00870)$ & 9,055 & 0.002 \\
\hline Real_Estate_Activities & $-7.932^{* *}$ & $(3.080)$ & 0.596 & $(0.701)$ & $0.280^{* *}$ & $(0.109)$ & 105 & 0.078 \\
\hline Renting_Other_Business & $-0.142^{* * *}$ & $(0.0365)$ & $0.204^{* * *}$ & $(0.0233)$ & $0.0416^{* * *}$ & $(0.00332)$ & 18,215 & 0.005 \\
\hline Public_Admin_Defence & $-0.246^{* * *}$ & $(0.0553)$ & $0.239^{* * *}$ & $(0.0338)$ & $0.0459^{* * *}$ & $(0.00451)$ & 12,134 & 0.005 \\
\hline Education & $-0.212^{* * *}$ & $(0.0647)$ & $0.373^{* * *}$ & $(0.0384)$ & $0.0731^{* * *}$ & $(0.00486)$ & 12,160 & 0.009 \\
\hline Health_Social Work & $-0.101^{*}$ & $(0.0609)$ & $0.246^{* * *}$ & $(0.0278)$ & $0.0688^{* * *}$ & $(0.00451)$ & 15,005 & 0.006 \\
\hline Other_Social_Personal_Services & $-0.379^{* * *}$ & $(0.102)$ & $0.323^{* * *}$ & $(0.0701)$ & $0.159^{* * *}$ & $(0.00972)$ & 11,131 & 0.002 \\
\hline Private_HH_Employed_Persons & $-0.307^{* * *}$ & $(0.0379)$ & $0.116^{* * *}$ & $(0.0234):$ & $0.110^{* * *}$ & $(0.00373)$ & 18,801 & 0.004 \\
\hline
\end{tabular}

Note: Robust standard errors in parentheses, ${ }^{* * *} \mathrm{p}<0.01,{ }^{* *} \mathrm{p}<0.05,{ }^{*} \mathrm{p}<0.1$ 
Figure 8: Bilateral exports, imports, and exchange rate for USA and other countries (Panel 1)

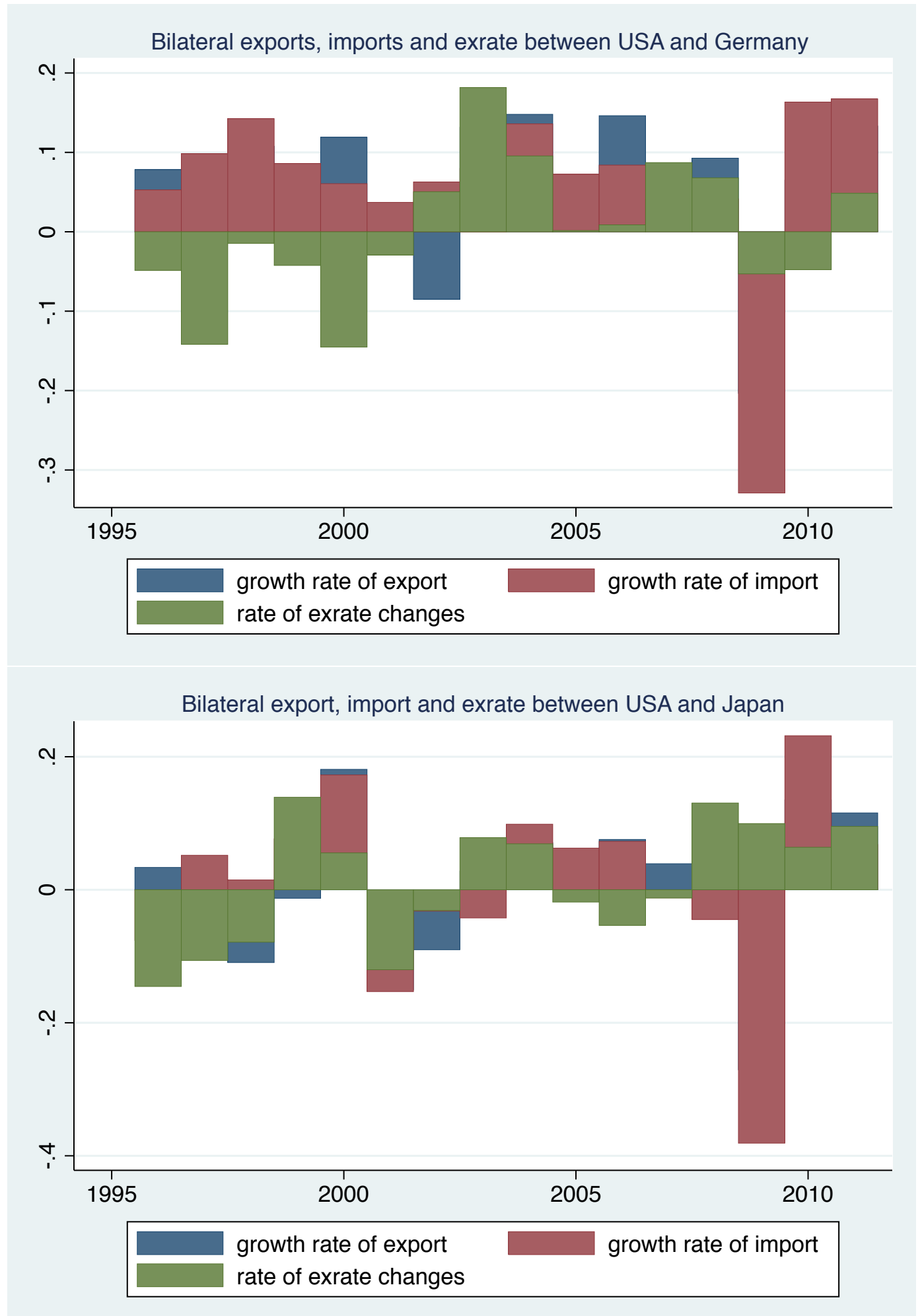


Figure 9: Bilateral exports, imports, and exchange rate for USA and other countries (Panel 2)

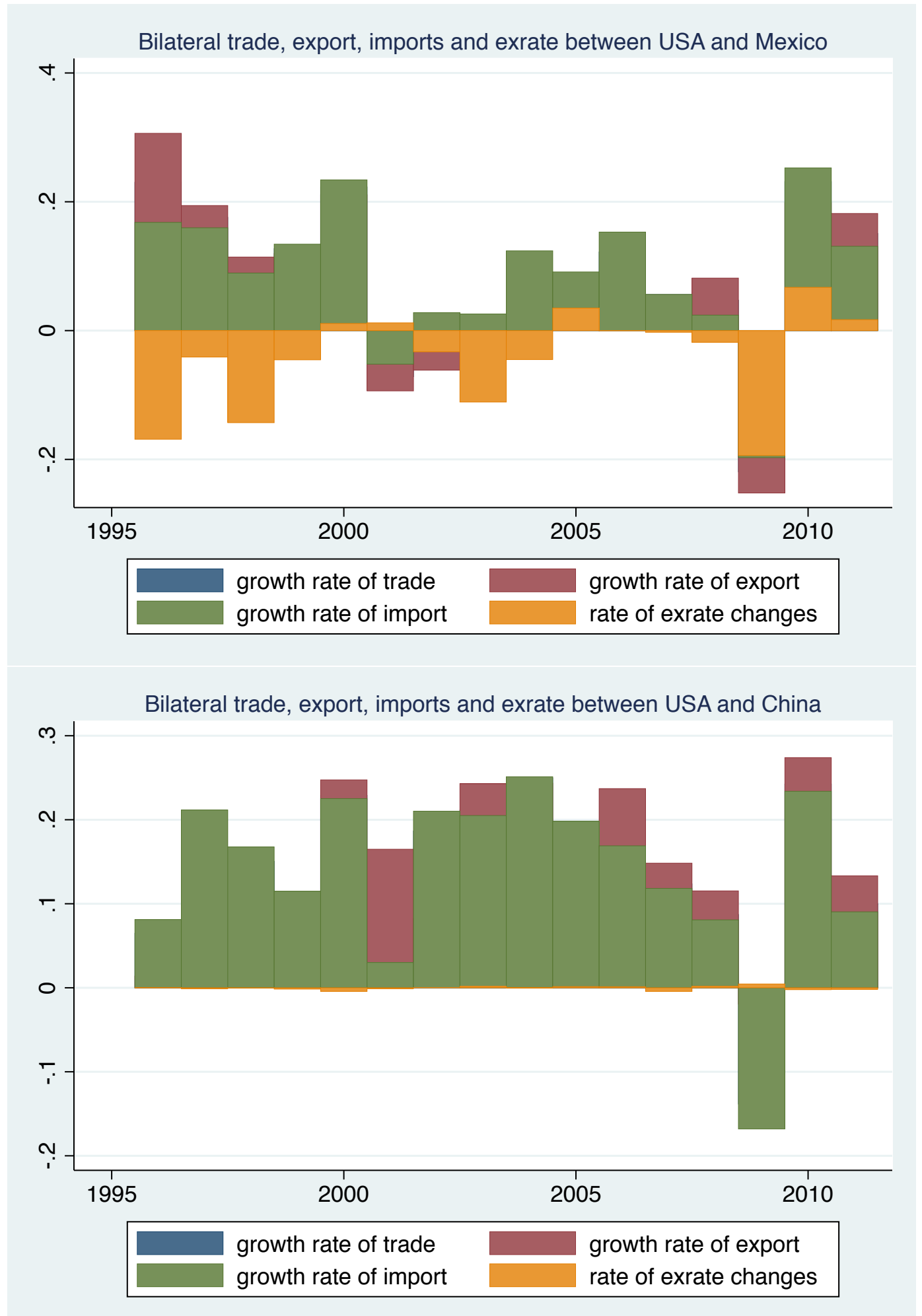


Figure 10: Bilateral exports, imports, and exchange rate for China and other countries (Panel 1)

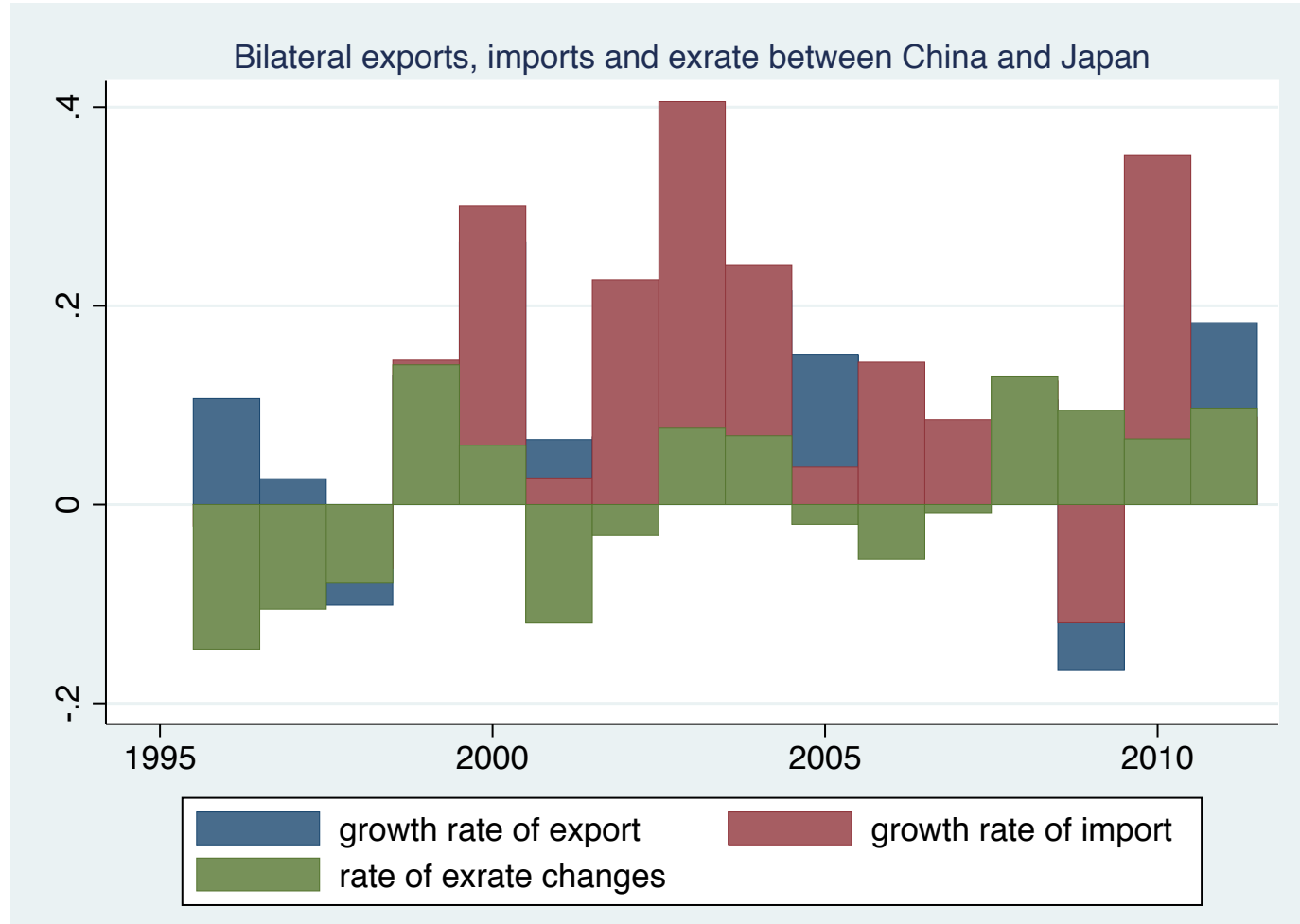

Bilateral exports, imports and exrate between China and Korea

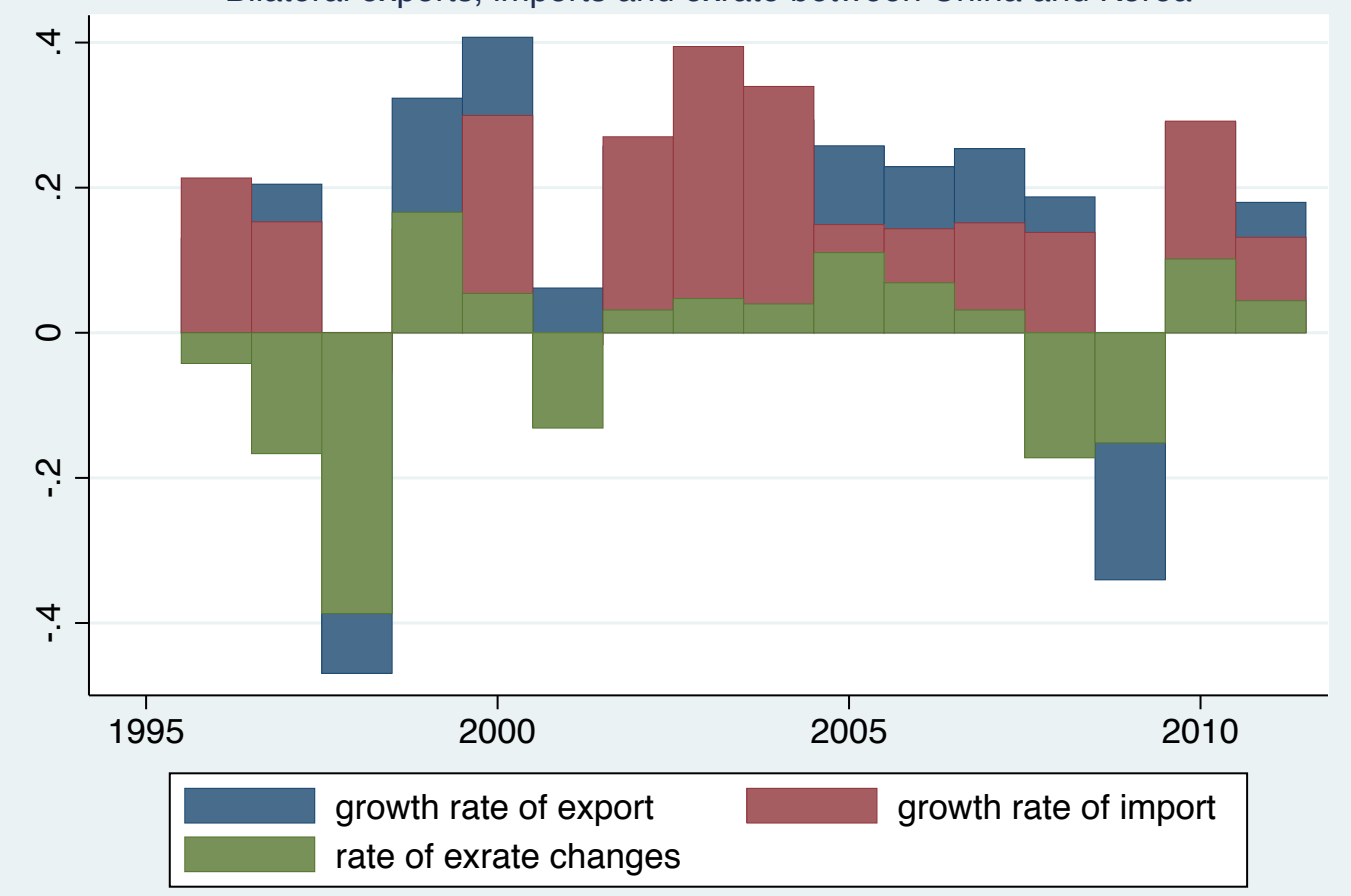


Figure 11: Bilateral exports, imports, and exchange rate for China and other countries (Panel 2)

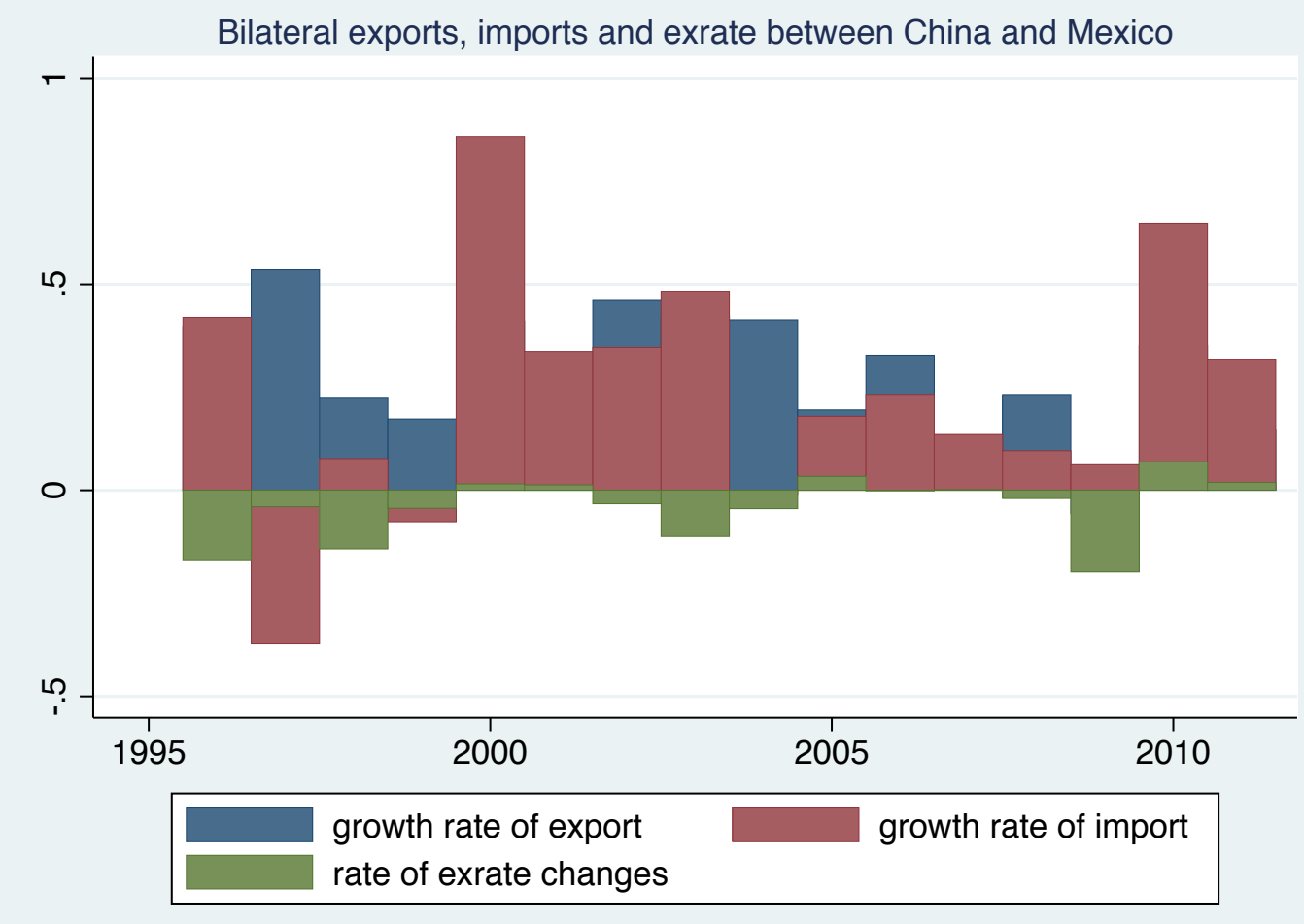

Bilateral exports, imports and exrate between China and USA

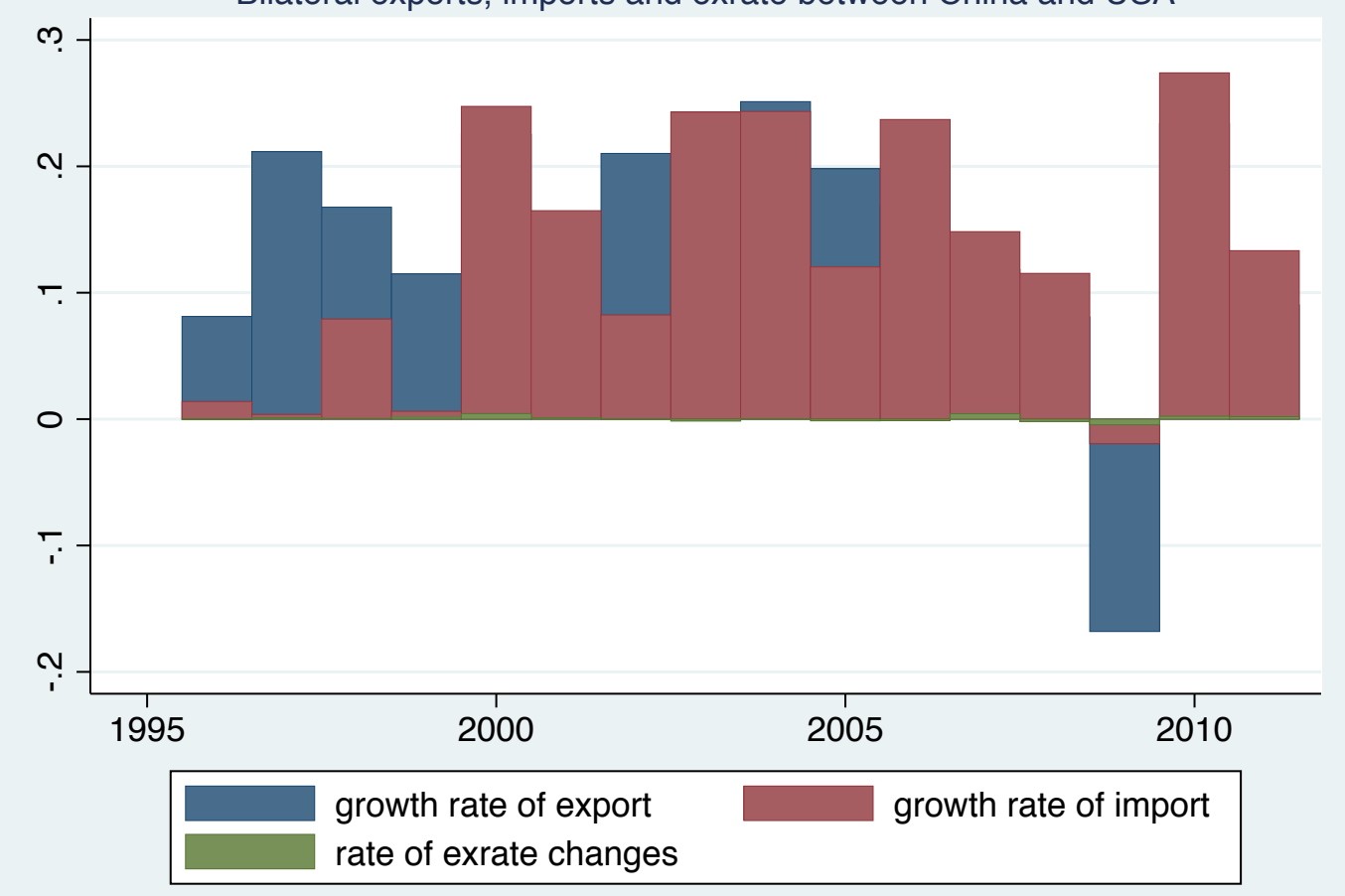


Figure 12: Bilateral exports, imports, and exchange rate for Germany and other countries (Panel 1)

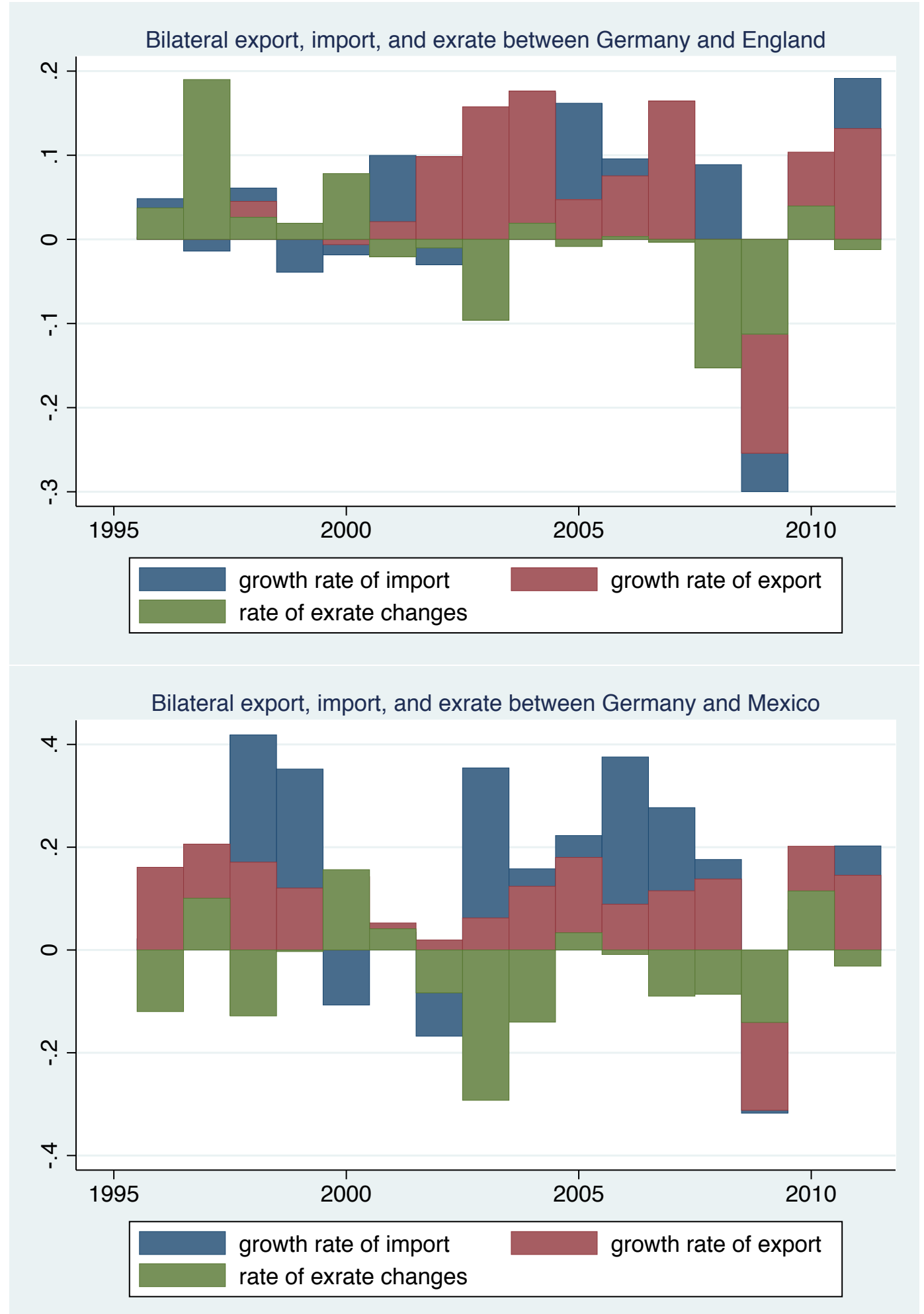


Figure 13: Bilateral exports, imports, and exchange rate for Germany and other countries (Panel 2)

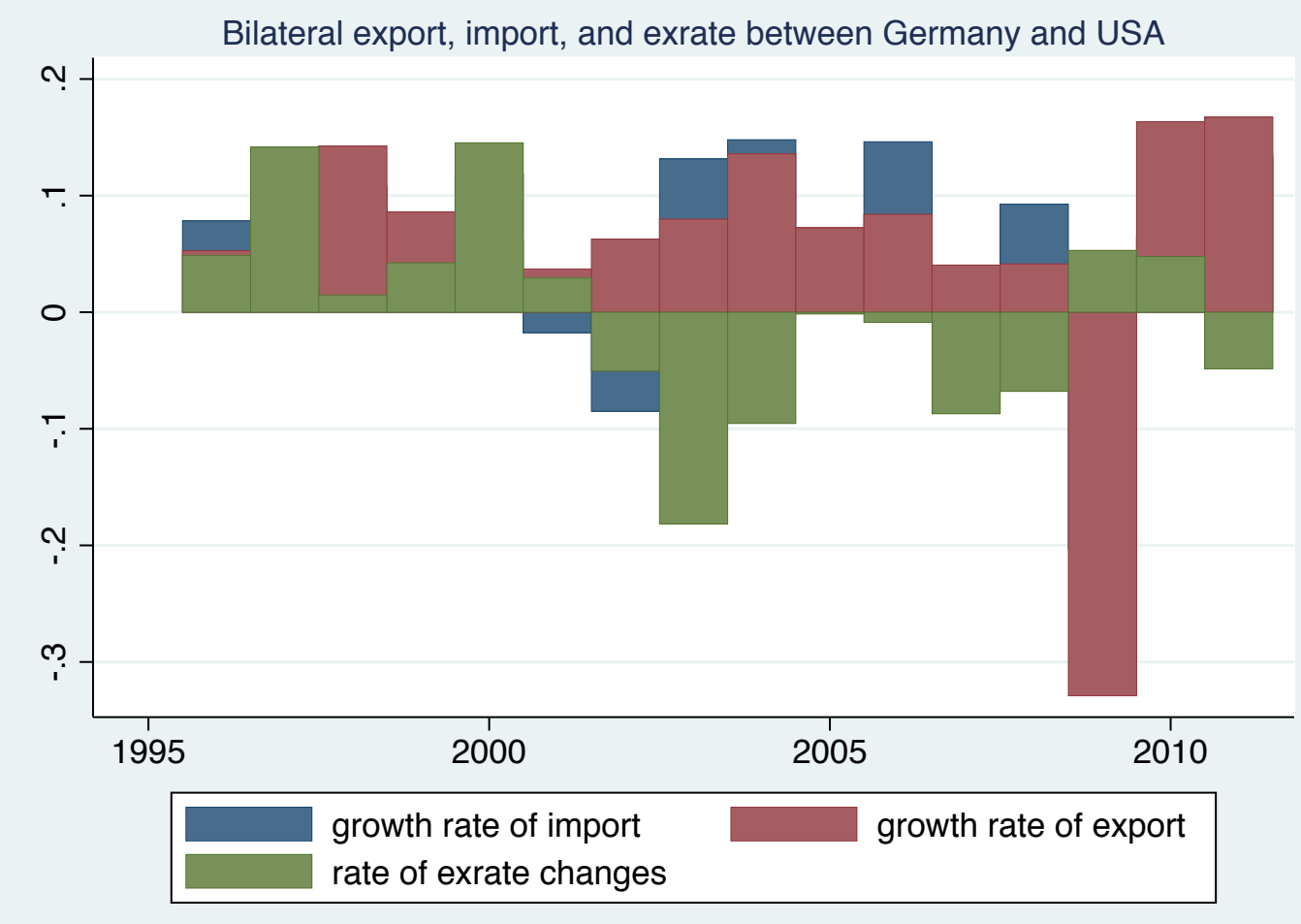

Bilateral export, import, and exrate between Germany and England

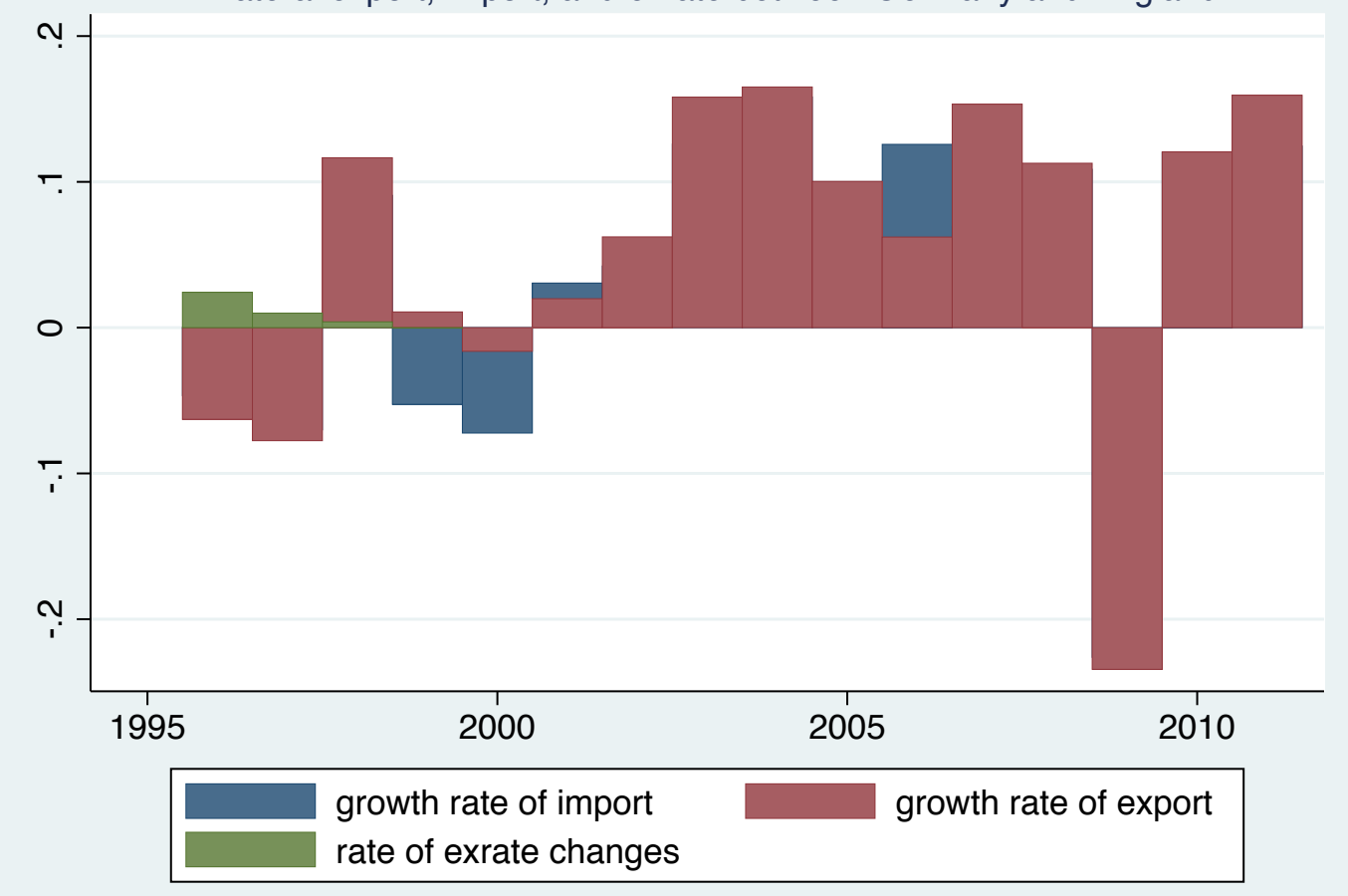


Figure 14: Gross and Value-added exports by sectors

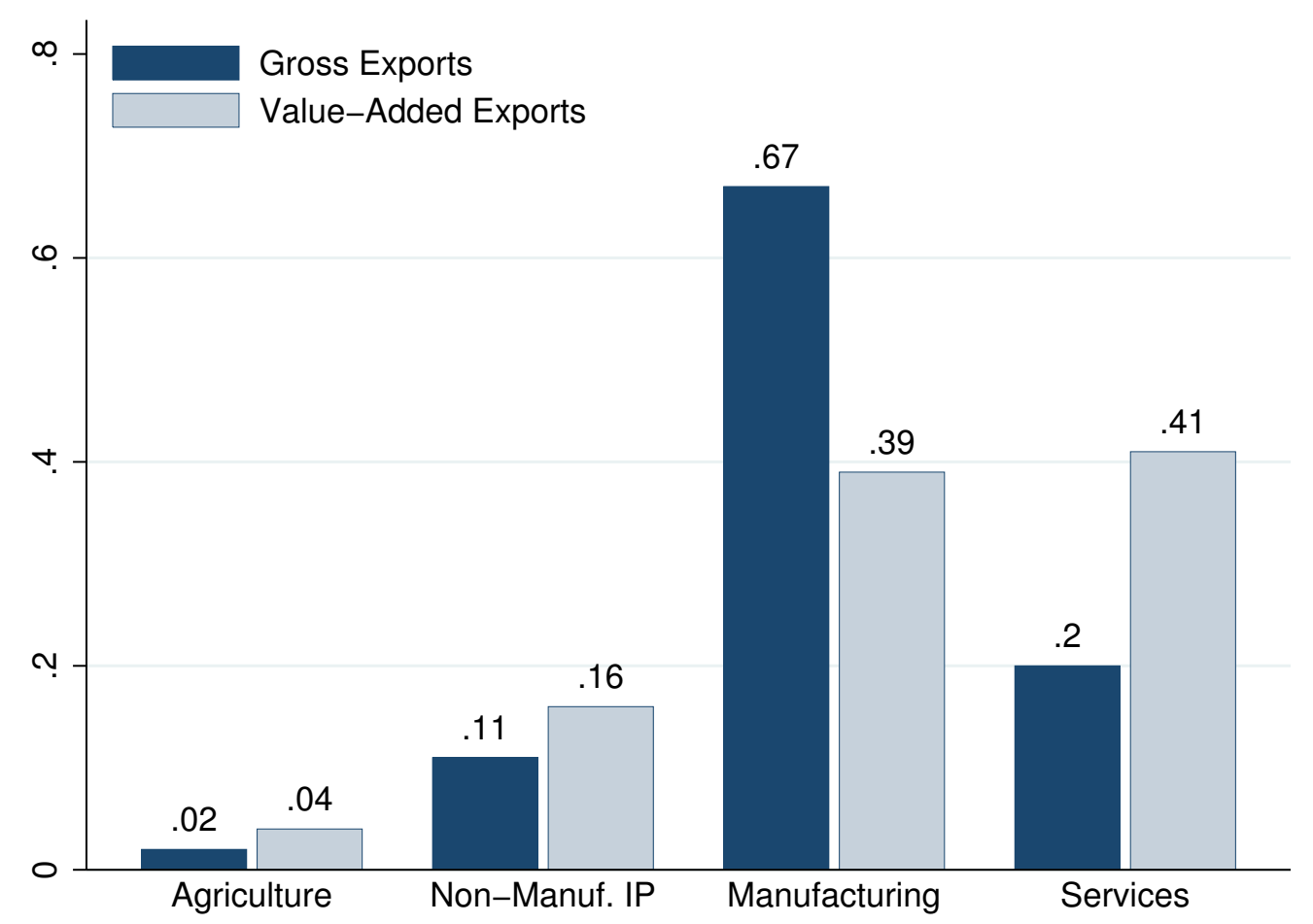

